\title{
Clemson University
}

\section{TigerPrints}

$5-2019$

\section{On the Edge of the World: Examining Pro- Environmental Outcomes of Last Chance Tourism in Kaktovik, Alaska}

Lauren Miller

Clemson University, lauren_0324@yahoo.com

Follow this and additional works at: https://tigerprints.clemson.edu/all_theses

\section{Recommended Citation}

Miller, Lauren, "On the Edge of the World: Examining Pro-Environmental Outcomes of Last Chance Tourism in Kaktovik, Alaska" (2019). All Theses. 3072.

https://tigerprints.clemson.edu/all_theses/3072

This Thesis is brought to you for free and open access by the Theses at TigerPrints. It has been accepted for inclusion in All Theses by an authorized administrator of TigerPrints. For more information, please contact kokeefe@clemson.edu. 


\section{ON THE EDGE OF THE WORLD: EXAMINING PRO-ENVIRONMENTAL OUTCOMES OF LAST CHANCE TOURISM IN KAKTOVIK, ALASKA}

A Thesis
Presented to
the Graduate School of
Clemson University
In Partial Fulfillment
Parks, Recreation, and Tourism Management
Master of Science
be the Ruirements for the Degree
bauren B. Miller
May 2019
Accepted by:
Jeffrey C. Hallo, Committee Chair
Matthew T.J. Brownlee
Wayne A. Freimund
Brian A. Peterson*

*non-voting member, graduate student mentor 


\section{EXTENDED ABSTRACT}

Last chance tourism (LCT), a relatively new tourism trend, has begun to emerge in which tourists seek out destinations with resources that are quickly disappearing.

Unfortunately, tourists visiting LCT locations may be contributing to their downfall. To help mitigate these impacts, a worthy goal of LCT would be the creation of environmental ambassadors. Polar bears (Ursus maritimus) are one species that inhabit a notable LCT destination. Polar bear viewing on the waters of the Arctic Refuge near the town of Kaktovik, AK has dramatically increased over the past decade. Small motorboats are used to view polar bears on shorelines. This creates a unique viewing opportunity characterized by eye-level experiences with polar bears in their natural environment. A formal management plan for polar bear viewing in the Kaktovik area of the Arctic Refuge is being formulated and is planned for implementation in the near future. The purpose of the current study is to help better understand and promote the proenvironmental outcomes of viewing polar bears in Kaktovik. The research questions that guided the study are as follows:

- Who are Arctic polar bear tourists that visit Kaktovik, Alaska and what was their experience like? Specifically, where are visitors from, what are their sociodemographic characteristics, is polar bear viewing their primary trip purpose, what is a typical trip and viewing experience, and what experiential elements are important to them?

- Is there a typology of visitors based on their trip motivations, and to what degree are experiential elements important to visitors based on this typology? 
- Does this experience lead to reported increases of pro-environmental outcomes (pro-environmental and ambassadorship behavior) for the Arctic environment and polar bears, and do these increases differ based on why visitors are motivated to visit Kaktovik?

- What elements of the trip (i.e., time on water, number of polar bears seen, difference between polar bears seen and expected, trip length, minutes of education, and occurrence of an epiphany) are impacting the reported likelihood of pro-environmental outcomes (pro-environmental and ambassadorship behavior)?

A visitor survey was developed using questions and techniques that have been adapted from those used in numerous parks and protected areas. Surveys were administered onsite in the two Kaktovik hotels, daily, between late-August and early-October 2017. Only tourists who had been on the water viewing polar bears were asked to complete the survey. A census approach was used, where each visitor encountered was asked to complete a survey. A total of 265 completed surveys were collected with 189 being used in analyses after being screened for outliers and missingness. It was found that the majority of visitors were middle-aged, well-educated, and traveling from within the United States. Day visitors made up over $60 \%$ of the visiting population. Visitors spent on average 3.7 hours on the water and saw approximately 20 polar bears, which was more than over $80 \%$ reported expecting to see. A typology of visitors was found, with three distinct groups being created, with motivators ranging from broad interests to a wildlife focus. When asked about various pro-environmental outcomes after their 
experience, visitors reported, on average, a change of being 'more likely' to partake in both pro-environmental and ambassadorship behaviors. Regression analyses revealed, for the sample population as a whole, that total minutes educated and the occurrence of an epiphany had a positive impact on visitors' reported pro-environmental behavior and ambassadorship intentions. Implications for management of similar experiences are discussed. 


\section{ACKNOWLEDGMENTS}

This thesis would not have been possible without the help of many amazing mentors and fellow graduate students along the way. I would like to thank my committee chair and advisor, Dr. Jeffrey Hallo, for welcoming me onto the Arctic Project and allowing me to follow my interests in the creation of this paper. Without his guidance and helpful feedback, this thesis would not have been possible. I would also like to thank my committee members, Dr. Matthew Brownlee and Dr. Wayne Freimund, whose various expertise allowed my thesis to grow in ways I never could have imagined. In addition, a thank you to Brian Peterson, an honorary member of my committee, whose guidance on SPSS allowed me to ask questions to which I could actually find the answers to. Finally, a thank you to Jessica Fefer, who was involved in the creation of the survey utilized in this research and leading on-site data collection in Kaktovik, Alaska. 


\section{TABLE OF CONTENTS}

Page

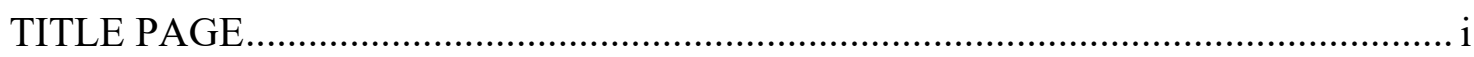

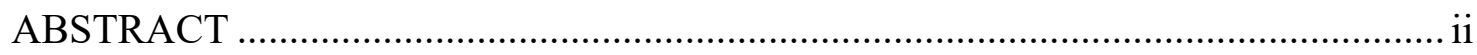

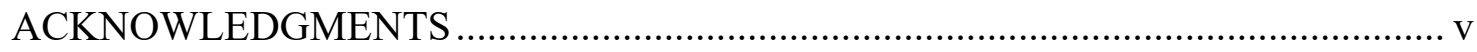

\section{MANUSCRIPT}

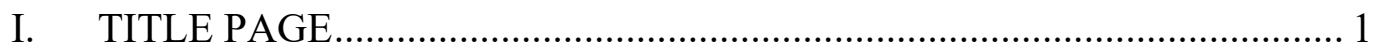

II. ABSTRACT [........................................................................... 2

III. INTRODUCTION ............................................................................ 3

IV. LITERATURE REVIEW ........................................................... 8

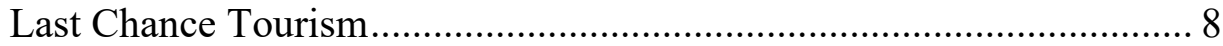

Polar Bears: Status and Tourism .................................................... 10

Pro-environmental Outcomes and LCT........................................... 11

Factors Influencing Pro-environmental Outcomes............................ 12

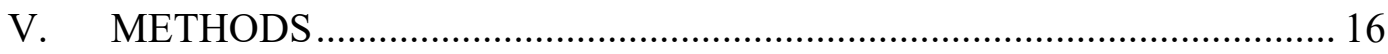

Data Collection .......................................................................... 16

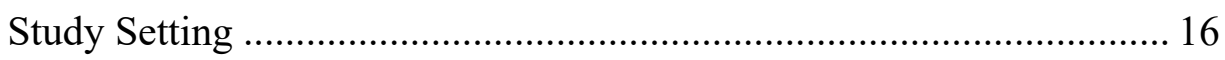

Visitor Surveys and Study Population................................................ 19

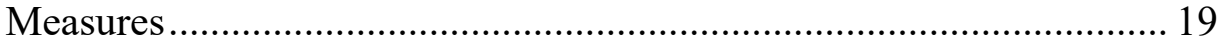

Data Screening and Set Up ...................................................... 20

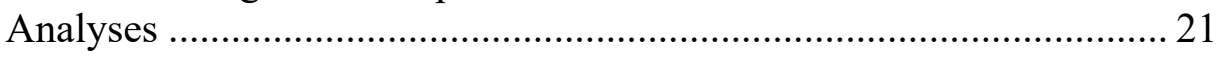

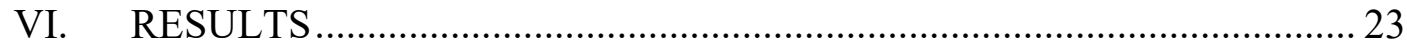

Visitor Profile and Trip Description................................................ 23

Visitor Motivation Groups and Group Differences............................ 24

Pro-environmental Outcomes ......................................................... 26 
Table of Contents (Continued)

Page

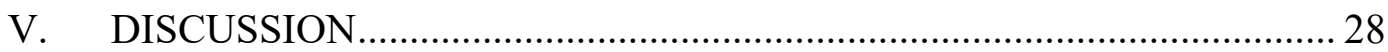

Management Implications ....................................................... 35

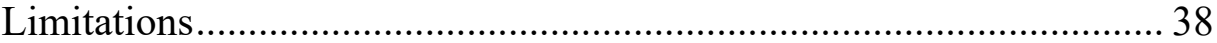

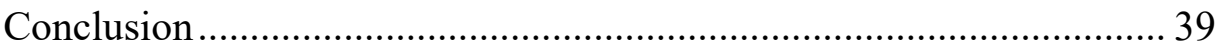

Funding Disclaimer .................................................................. 4

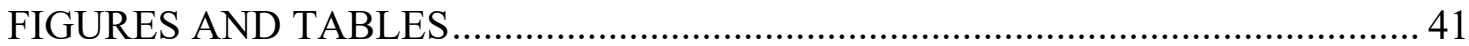

Figure 1: Polar bear tourism locations in the Arctic with subpopulation range overlay ................................................ 41

Figure 2: Model of last chance tourism ............................................ 42

Figure 3: Interactional theory framework applied to LCT viewing characteristics..................................................... 43

Figure 4: Importance of various experiential element composite means by cluster groups ............................................ 44

Table 1: Importance score of various polar bear viewing experiential elements overall and by cluster group ...................... 45

Table 2: Demographic characteristics overall and by cluster groups .. 46

Table 3: Trip characteristics summary overall and by cluster groups . 47

Table 4: Pro-environmental outcomes overall and by cluster groups .. 48

Table 5: Multiple linear regression analyses

APPENDIX: 2017 Phase I Visitor Survey .......................................................... 50

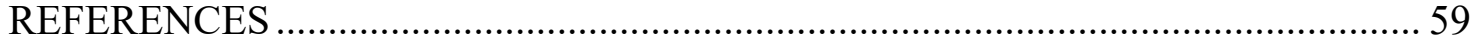


On the edge of the world: Examining pro-environmental outcomes of last chance tourism in Kaktovik, Alaska

Lauren B. Miller ${ }^{1}$, Jeffrey C. Hallo ${ }^{1}$, Robert Dvorak ${ }^{2}$, Jessica P. Fefer ${ }^{3}$, Brian A. Peterson $^{1}$, Matthew T.J. Brownlee ${ }^{1}$, Wayne A. Freimund ${ }^{1}$

${ }^{1}$ Department of Parks, Recreation, and Tourism Management Clemson University

${ }^{2}$ Department of Recreation, Parks, and Leisure Services Administration Central Michigan University

${ }^{3}$ Department of Horticulture and Natural Resources

Kansas State University 
Running heading: EXAMINING PRO-ENVIRONMENTAL OUTCOMES OF LAST CHANCE TOURISM

\begin{abstract}
Travel to impact-sensitive destinations has been on the rise in recent years. Coined last chance tourism (LCT), visitors are flocking to these imperiled destinations to see them before they are gone. To off-set their presence, which ultimately contributes to site degradation, a possible positive outcome of these LCT experiences is the creation of environmental ambassadors. Utilizing data collected from 189 visitor surveys, the purpose of this study is to provide a basis for understanding the visitor experience and outcomes of boat-based polar bear viewing in the Kaktovik area of the Arctic National Wildlife Refuge. This study contributes to current literature by examining a diversity of experiential factors in a LCT destination and how they contribute to pro-environmental outcomes (pro-environmental and ambassadorship behavior). A typology of visitors was created based on importance of various trip elements, and demographic and trip characteristics were examined by resulting groups. Analyses show that the polar bear viewing experience does have the potential to increase visitors' pro-environmental and ambassadorship behavioral intentions. Regression analyses revealed, for the sample population as a whole, that total minutes educated and the occurrence of an epiphany had a positive impact on visitors' reported pro-environmental behavior and ambassadorship intentions. Surprisingly, seeing more polar bears was negatively related to these same intentions. Implications for management of similar experiences are discussed.
\end{abstract}

Keywords: last chance tourism, climate change, pro-environmental behaviors, environmental epiphanies, environmental interpretation, ambassadorship, Arctic 
EXAMINING PRO-ENVIRONMENTAL OUTCOMES OF LAST CHANCE TOURISM

\section{INTRODUCTION}

Humans have been traveling to new tourism destinations for centuries and the locations and activities they seek are often unique or novel (Walton, 2015). A new tourism trend that has begun to emerge is one in which tourists seek out destinations with resources that are quickly disappearing. Iconic locations, such as the Great Barrier Reef, the Galapagos Islands, and polar regions are all places experiencing an increase in visitors (Lemelin, Dawson, Stewart, Maher, \& Leuck, 2010). This increase in travel to impact-sensitive and imperiled destinations has been officially coined last chance tourism (LCT), where "tourists explicitly seek vanishing landscapes or seascapes, and/or disappearing natural and/or social heritage" (Lemelin et al., 2010, p.248). Value placed on resources is highly dynamic and the LCT market capitalizes on the evolution of destination interest (Zimmerman, 1951). A dilemma in this new trend is the increase in tourism inflating impacts on LCT ecosystems, especially since most of these sites are located in remote areas that are climate-sensitive and require long-haul travel (Dawson et al., 2011). Tourists visiting LCT locations may ultimately just accelerate their downfall (Lemelin et al., 2010). However, a worthy goal of LCT would be to help increase the awareness and conservations actions of visitors to these locations, perhaps mitigating impacts contributing to their demise.

Polar bears (Ursus maritimus) are a prominent species that inhabit notable LCT destinations. The melting of polar ice caps and reduction of sea ice that serve as their critical habitat in the Arctic environment have resulted in both the species and their domain becoming a significant representation of climate change (Dawson et al., 2011). 
EXAMINING PRO-ENVIRONMENTAL OUTCOMES OF LAST CHANCE TOURISM

The Arctic is facing pressures from changing climate (some areas experiencing an increase of $3^{\circ} \mathrm{C}$ in average winter temperatures over 60 years), tourism growth, and oil production (Gössling \& Hall, 2006; Kaltenborn \& Emmelin, 1993). Issues facing polar bears include difficulties accessing hunting habitat (i.e., sea ice melt), pollution, and human conflict (USFWS, 2016). The Arctic is home to nineteen subpopulations of polar bears world-wide, of which two exist in the United States (i.e., Southern Beaufort Sea and Chukchi) and are listed as threatened according to the U.S. Endangered Species Act (USFWS, 2016). This threatened status makes them a focus of LCT as well. The Southern Beaufort Sea subpopulation of polar bears occupy waters surrounding Kaktovik, Alaska year-round with bears concentrated there late-August through midOctober. This creates an ideal LCT opportunity to view polar bears, while experiencing the Arctic environment.

When facilitated correctly, environments and experiences like those surrounding polar bears have the potential to offset the negative impacts of tourists' presence. This can occur when visitors leave informed on the issues surrounding the environment and are inspired to conduct pro-environmental behaviors and promote the destinations 'cause' by becoming ambassadors (Lemelin, et al., 2010; Maher, Steel, \& McIntosh, 2003; Powell, Kellert, \& Ham, 2008). Pro-environmental behaviors are those that one completes to consciously minimize their negative impact on the Earth's resources (Kollmuss \& Agyeman, 2002). An ambassador, in the most basic sense, is a representative or promotor (Ambassador, n.d.). Therefore, environmental ambassadors represent or promote natural areas, like those in which LCT experiences take place. 
EXAMINING PRO-ENVIRONMENTAL OUTCOMES OF LAST CHANCE TOURISM

Ambassadors are empowered when knowledge is gained to actively educate others about LCT destinations or resources, threats to them, and ways to restore or protect them.

Various studies have tested aspects of the LCT experience and whether that experience leads to a rise in pro-environmental behaviors and the creation of ambassadors. These aspects include: interpretation, feelings of awe, overall itinerary, and levels of interaction with LCT resources (Ballantyne, Packer, Hughes, \& Dierking, 2007; Hungerford \& Volk, 1990; Powell, Brownlee, Kellert, \& Ham, 2012). Results from some studies suggest that LCT experiences and interactions can create increases in these proenvironmental outcomes. For example, Beaumont (2001) found that environmentallybased experiences that increase visitor knowledge can influence visitors' views and behaviors related to conservation. Existing research typically examines only one or a few elements of an experience to see if they increase the potential for ambassadorship creation (e.g., Ballantyne et al., 2007; Hungerford \& Volk, 1990; Orams, 1997). The relationship between trip characteristics and ambassadorship creation is complex, and even those studies that examine multiple variables suggest that more research is necessary (Powell et al., 2012; Powell, Kellert, \& Ham, 2009; Skibins, Powell, \& Hallo, 2013). Further evidence, including the examination of a diversity of experiential factors and LCT contexts, is imperative to support the notion that LCT can create passionate ambassadors and spur conservation behaviors (Lemelin et al., 2010). With rapid growth in LCT around the world adding to the diminishment of these destinations, studies are increasingly requisite in helping managers, tour operators, and guides to promote proenvironmental outcomes and justify LCT experiences (Powell et al., 2008). 
EXAMINING PRO-ENVIRONMENTAL OUTCOMES OF LAST CHANCE TOURISM

This research will contribute to a relatively new but growing body of literature by examining a suite of experiential variables potentially important to creating LCT ambassadorship for threatened polar bears in the climate-impacted areas surrounding Kaktovik, AK. Specifically, it will examine if visitors' likelihood to participate in proenvironmental and ambassadorship behaviors are influenced by the following variables: length of time on water, length of stay in Kaktovik, number of polar bears seen and if that number matched or differed from their expectations, total time spent being educated about polar bears and the Arctic environment, and the occurrence of an environmental epiphany. The context of Kaktovik, AK is a prime location for the examination of LCT related to polar bears and the Arctic environment because most published studies about this phenomenon have occurred in Churchill, Manitoba (Lemelin, Stewart, \& Dawson, 2012). Kaktovik provides tourists with a more intimate experience featuring minimal development and perceived commercialization that is lightly managed by the governing authorities. These differences in context may influence behavioral change and the creation of ambassadors in ways that differ from the existing literature and might have implications for other similar Arctic LCT contexts. This research will address the following research questions:

- Who are Arctic polar bear tourists that visit Kaktovik, Alaska and what was their experience like? Specifically, where are visitors from, what are their sociodemographic characteristics, is polar bear viewing their primary trip purpose, what is a typical trip and viewing experience, and what experiential elements are important to them? 
- Is there a typology of visitors based on their trip motivations, and to what degree are experiential elements important to visitors based on this typology?

- Does this experience lead to reported increases of pro-environmental outcomes for the Arctic environment and polar bears, and do these increases differ based on why visitors are motivated to visit Kaktovik?

- What elements of the trip (i.e., time on water, number of polar bears seen, difference between polar bears seen and expected, trip length, minutes of education, and occurrence of an epiphany) are impacting the reported likelihood of pro-environmental outcomes? 


\section{LITERATURE REVIEW}

\section{Last Chance Tourism}

Tourism companies and operators are using LCT to market unique opportunities and draw more visitors to fragile and imperiled locations (Dawson et al., 2011). Yet, visiting a destination that has suffered a negative change from natural disasters or human impact is not a new interest to tourists (Lemelin et al., 2012). This trend has only recently taken on names such as 'doom', 'disappearing', or 'gloom tourism' (Lemelin et al., 2010). Tourists are seeking imperiled destinations that have the potential to disappear forever, while contributing to their demise. These locations are typically fragile environments that need little effort to be negatively impacted. Visitors to these destinations seem to understand the need for conservation efforts and the impact they are creating, yet their desire to visit outweighs this understanding (Dawson et al., 2011).

Many locations worldwide are feeling the impact of the increasing demand for LCT. New Zealand has a multimillion-dollar glacier tourism business (Purdie, 2013). Tourism to New Zealand's glaciers began over 100 years ago and current climate changeinduced melting is causing major impacts to primary glacier tourism locations (Stewart et al., 2016). With the threat of glaciers disappearing and increased marketing, interest is growing and New Zealand is seeing a rise in this type of tourism. Though this industry is threatened by glacial retreat, a shorter freezing time has unfortunately allowed operators to increase the tourism season (Purdie, 2013).

The tourism industry is one of the fastest growing industries of the Galapagos Island economy (Epler, Watkins, \& Cárdenas, 2008). Made up of 120 islands and home 
EXAMINING PRO-ENVIRONMENTAL OUTCOMES OF LAST CHANCE TOURISM

to many endemic species, these islands are $97 \%$ protected national park land. This unique destination started seeing visitors in the 1960s, and visitation has steadily increased in decades since (Powell \& Ham, 2008). The Galapagos Islands face many environmental impacts that endanger the tourism destination and its resources, such as overfishing, invasive species introduction, and climate change-induced drought (Powell \& Ham, 2008).

The Great Barrier Reef has been labeled a LCT destination by the popular media after a decline in reef health led to a decrease in tourism revenue. The last 40 years has seen a substantial decline in coral coverage. Climate change is just one driver of impacts along with bleaching, over-harvesting, and dredging. After being labeled a LCT destination, tourists started to flock to the reef to 'see it before it's gone.' Although tourists help the tourism industry, they also have negatively impacted the reef (PiggottMcKellar \& McNamara, 2017).

The United Nations Educational, Scientific, and Cultural Organization (UNESCO) in partnership with the International Union for Conservation of Nature (IUCN) has begun to develop a 'danger list' of UNESCO World Heritage Sites that are at risk. Sites are deemed at risk when populations of native species are in decline, the property is threatened by human action, no formal management plan is in place, or protective status is at risk (UNESCO, 2008). These requirements match many characteristics of locations coined LCT destinations and could eventually become hotspots for LCT visitation. This 'danger' list, which has 54 sites, includes Glacier National Park in Montana, USA; Everglades National Park in Florida, USA; Chan Chan 
EXAMINING PRO-ENVIRONMENTAL OUTCOMES OF LAST CHANCE TOURISM

Archeological Zone in Peru; and Rio Plátano Biosphere Reserve in Honduras (World Heritage Committee, 2018).

\section{Polar Bears: Status and Tourism}

Polar bears are a universally known symbol of climate change that were listed as vulnerable on the IUCN Red List in 2015 (Wiig et al., 2015). Gleason and Rode (2009), when studying the locations of bears in the Southern Beaufort Sea population, found less bears out on ice and more in open water compared to historical data. They reasoned that this behavior change was due to worsening ice conditions and variation in freezing times. This increase in polar bears coming close to shore has made viewing easier but has also increased the possibilities of human-bear conflict and concerns for safety (Wilson et al., 2017). Bears also face the challenge of finding calorie-dense food in a terrestrial environment that they are not suited to hunt in. They are carnivores specially adapted to hunt on ice for bearded or ringed seals (Atwood et al., 2016; Bromaghin et al., 2015; Fitzgerald, 2013). Being an apex predator, they are sensitive to changes and are at an elevated risk for their populations to decline suddenly (Bromaghin et al., 2015). A study conducted in 2017 found that about 15\% of the southern Beaufort Sea population lives on the coast between late August and late October (Wilson et al., 2017). This number is estimated to rise with continued ice loss and shortening periods of full freeze (Atwood et al., 2016).

Polar bear tourism seems to be increasing in popularity and accessibility. Also, with melting sea ice opening up opportunities to capitalize on the resources, the Arctic has emerged as a 'hot' location (Avango, Nilsson, \& Roberts, 2013). Tourists visit select 
EXAMINING PRO-ENVIRONMENTAL OUTCOMES OF LAST CHANCE TOURISM

locations to mainly view and photograph polar bears in their natural habitat (Lemelin \& Dyck, 2007). An alternative tourism activity, sport hunting, also occurs in parts of Nunavut, Canada with members of the Inuit community (Dowsley, 2008). With growing public awareness of the status of this iconic species, travel to the Arctic has started growing exponentially (Born, 2018; Lemelin \& Wiersma, 2007). There are five sites globally that are best known for predictable and consistent populations of polar bears (Figure 1). These include Kaktovik, Alaska; Churchill, Canada; Svalbard, Norway; Nunavut, Canada; and Wrangel Island, Russia (Lemelin \& Dyck, 2007). LCT in Kaktovik, Alaska and other destinations worldwide has the potential to provide financial support to the host community and support for conservation efforts in these fragile environments if managed in an efficient and effective manner (Trave, Brunnschweiler, Sheaves, Diedrich, \& Barnett, 2017). However, this potential can come at a cost with visitors being labeled as polar mass market tourists since climate change and their impact to the environment were of little or no concern; their desire to travel and consume sensitive environments outweighs their support for conservation (Dawson et al., 2011).

\section{Pro-environmental Outcomes and LCT}

In order to break the paradox created by LCT visitors as shown in Figure 2, a worthy goal for LCT providers is for their experience to lead to pro-environmental outcomes. Research shows that properly designed LCT trips and experiences have the potential to mitigate the negative impacts of tourism and increase the cultivation of environmental ambassadors (Eijalaar, Thaper, \& Peeters, 2010; Powell \& Ham, 2008). These mitigations can come in the form of pro-environmental behavioral change that 
EXAMINING PRO-ENVIRONMENTAL OUTCOMES OF LAST CHANCE TOURISM

usually occurs after the development of environmental concern (Kollmuss \& Agyeman, 2002). Ambassadorship was first used in an environmental context when tourism to Antarctica began in the 1960s (Vila, Costa, Angulo-Preckler, Sarda, \& Avila, 2016). In relation to Antarctic tourism expeditions, it has been discussed that experiencing the 'ice' in person leads visitors to advocate for its protection (Burton, 2000). Boo (1990) states this is caused by the formation of an emotional connection that makes tourists want to help improve the area's conservation status. This idea transfers to additional finding that visits to protected areas can contribute to learning, change opinion, and an increase commitment (Cessford, 1995). Unfortunately, some studies have found that even when pro-environmental behavioral intentions increase post-trip, only behaviors that demand low costs are usually carried out (Kollmuss \& Agyeman, 2002). In addition, it has been found that those traveling to LCT destinations are already committed to conservation and therefore cannot be influenced further (Beaumont, 2001). This broad range of outcomes shows that the LCT experience is rich and complex, with each experience being full of varying factors that make it unique (Powell et al., 2012). Therefore, understanding what influences an experience will help in developing LCT management plans that lead to growth in conservation support of visitors (Lemelin \& Smale, 2006).

\section{Factors Influencing Pro-environmental Outcomes}

Research has just begun to analyze the contributing factors making a successful LCT experience that leaves guests satisfied and creates conservation supporters. With LCT destinations being unique in the levels of threats facing them, LCT operators and managers must create a unique plan to mitigate the negative impact of their visitors. 
EXAMINING PRO-ENVIRONMENTAL OUTCOMES OF LAST CHANCE TOURISM

Combining past studies and finding the characteristics unique to each experience that maximizes ambassadorship creation is the path for managers to take that can increase members of local or global communities that are educated and supportive of conservation initiatives (Powell et al., 2008).

Interactional theory. There is a constant exchange occurring between an individual, their environment, and an experience (Skibins, Powell, \& Hallo, 2016). This exchange and its impacts on behavior is referred to as interactional theory. When applied to LCT, "the characteristics of a nature-based tour are seen as an influential part of the interaction between the tourist, the host site, fellow travelers, and land management agencies" (Powell, Kellert, \& Ham, 2009, p. 764). For example, Powell et al. (2012) found that guide characteristics, infrastructure, weather, and other factors can impact a visitor's satisfaction with their trip. Age, gender, education level, prior knowledge, and attitudes and beliefs can also influence the outcomes of an experience (Powell et al., 2009). Given this knowledge, and the adapted interactional theory, various key experiential elements that can be influenced by management are examined more closely below.

Time. Time has been found to have an influence on the success and environmental focus of participants in an environmental experience (McKay, Brownlee, \& Hallo, 2012). A study analyzing the differences between a one-day and five-day experience found that both programs had an increase in knowledge, but only the five-day experience saw significant change in behavior (Bogner, 1998). Stern, Powell, and Ardoin (2008) found that participants in a 5-day program showed a significantly greater increase 
EXAMINING PRO-ENVIRONMENTAL OUTCOMES OF LAST CHANCE TOURISM

in various short-term pro-environmental outcomes (e.g., stewardship, interest in discovery, awareness) over 3-day program participants. However, the long-term proenvironmental outcomes were only significant for the outcome of environmental awareness between 3-day or 5-day program participants. This shows that though time in an immersive environmental experience can be impactful, gains can vary by length of experience and over time once removed from the environment.

Iconic Species. It was found in a study by Colléony, Clayton, Couvet, Saint Jalme, and Prévot (2017) that more people choose to donate to charismatic species over those designated as endangered. Wolves, after being reintroduced to Yellowstone National Park in March of 1995, replaced bears as the iconic species of the park. Visitors to Yellowstone, after reintroduction, often reported that viewing wolves in the park had a meaningful impact on their lives (Montag, Patterson, \& Freimund, 2005). Polar bear viewers to Churchill Canada reported that the number of bears seen on a viewing excursion was the greatest influence of their satisfaction (Lemelin \& Smale, 2006). A study conducted by Skibins et al. (2013) analyzed visitors' connection to charismatic megafauna and its influence on pro-environmental behaviors. Their research found that viewing an interesting animal has the potential to enhance pro-conservation perspectives in viewers.

Education. Environmental education-based interpretation usually sets out to foster responsible behavior toward the environment, influence attitude changes, and provide basic knowledge (Bogner, 1998). Though not all interpretive programs result in positive change, the most successful environmental interpretation programs usually hit on 
a few key elements: curiosity, affective domain, motivation creation, and suggestion of actions (Orams, 1997). A study conducted by Orams (1997) evaluating an educational program in Australia found desirable changes occurring in program participants. The direct environmental interaction and the information provided resulted in new attitude and behavior formation (Orams, 1997). However, other findings have found that contextualized knowledge gain from these experiences are typically low (Pooley \& O’Connor, 2000). Environmental education has the potential to change behavior by creating knowledgeable people but only if LCT operators and managers provide learning opportunities that incorporate information in a thoughtful and effective way so that visitors become motivated to subsequently employ pro-environmental behaviors (Hungerford \& Volk, 1990).

Epiphany. An environmental epiphany is a type of emotional experience in nature. It is defined more precisely by Vining and Merrick (2012) as "an experience in which one's perception of essential meaning of her/his relationship with nature shifts in a meaningful manner” (p. 497). Vining and Merrick (2012) also broke environmental epiphanies down into 5 types: aesthetic, intellectual, realization, awakening, and connectedness (Vining \& Merrick, 2012). These epiphanies and resulting heightened emotions can come from being immersed in a location that is vast and unique (Pooley \& O'Connor, 2000). This aligns with a study by Beaumont (2001) that found experiences in natural settings had a positive impact on developing conservation ethic in visitors. 
EXAMINING PRO-ENVIRONMENTAL OUTCOMES OF LAST CHANCE TOURISM

\section{METHODS}

\section{Data Collection}

Data were collected in the town of Kaktovik, Alaska, U.S.A. using visitor questionnaires during the 2017 polar bear viewing season (late August through early

October). Participants were selected from visitors that went polar bear viewing on commercially-guided boats. Unguided or exclusively land-based polar bear viewing by tourists does not occur to any known extent in Kaktovik.

\section{Study Setting}

Kaktovik, Alaska is an Inupiat community located on Barter Island, along the Southern Beaufort Sea. The village is surrounded by lands and waters that are a part of the Arctic National Wildlife Refuge (Arctic Refuge). According to a census completed by the North Slope Borough in 2016, 262 residents, of which $88 \%$ are Inupiat, live yearround in this extremely remote community and are heavily reliant on the natural resources of the area for their subsistence (Kaktovik, 2018). These subsistence activities include an annual hunt and harvest of Bowhead Whales (Balaena mysticetus). The remaining bones and scraps of subsistence-harvested Bowhead Whales attract a relatively large number of scavenging polar bears to the community in August through October each year. These bears are members of the Southern Beaufort Sea subpopulation ( 900 individuals) that is listed as 'in decline' (Bromaghin et al. 2018). In addition to the food source provided by the whale remains, polar bears are spending more time near the shores of Kaktovik. This is because of the growing loss of Arctic sea ice and its retreat farther from shore every year that results in the loss of critical hunting habitat for polar 
EXAMINING PRO-ENVIRONMENTAL OUTCOMES OF LAST CHANCE TOURISM

bears. The prevalence of polar bears has created an especially strong connection, economically and socioculturally, between the community and the polar bears themselves.

Polar bear tourism is relatively new to Kaktovik. This recent tourism influx is partly due to a United States Fish and Wildlife Services (USFWS) grant issued in 2004 that helped local residents purchase boats for bear viewing, though exponential growth did not start to occur until 2011(USFWS, 2015). It has been found that between 2011 and 2017 the number of polar bear viewers (measured as 'viewing days') in Kaktovik increased dramatically from 260 to 3,015 per season (USFWS, 2018). Also, the percentage of days on which polar bear viewing takes place increased during this same time from $38 \%$ to more than $81 \%$ of the viewing season's days (USFWS, 2018).

Boat-based viewing is provided by 16 operators that are permitted by a USFWS Special Use Permit. Small motorboats are used to carry six or less tourists at a time to view polar bears on shorelines. This creates a unique viewing opportunity characterized by eye-level experiences with polar bears in their natural environment with few physical barriers between tourists and the bears themselves. Boat captains and guides are asked to comply with a voluntary minimum buffer of 30 yards (approximately 27 meters) to a polar bear during viewing (USFWS, 2018). Boat-based viewing allows flexibility and maneuverability to maintain distance and to control the viewing experience and its impacts based on bear behavior.

Visitors typically either fly in for the day or stay multiple nights in one of two local accommodations. Day visitors pay approximately $\$ 1800$ to fly to Kaktovik, eat 
EXAMINING PRO-ENVIRONMENTAL OUTCOMES OF LAST CHANCE TOURISM

lunch, and view polar bears on the water for three hours with a captain and/or guide before leaving. Overnight visitors pay $\$ 3,000$ to upwards of $\$ 12,000$ to fly to Kaktovik, stay overnight, and view polar bears on the water for four to eight hours per day on multiple days. To the extent possible, all visitors are met by a USFWS staff member at some point during their visit for an educational briefing. This briefing includes basic information on polar bears, their population status, and the influence of a warming Arctic environment and sea ice loss on their population. Commercial boat captains and guides also provide education to visitors while on the water.

The ocean waters surrounding Kaktovik, where polar bears are viewed by commercially-guided tourists, are a part of the Arctic Refuge. These waters are managed and regulated by the USFWS. Polar bears themselves are strictly protected and managed through legislation and USFWS efforts. However, as of 2017, a formal management plan did not exist for polar bear tourism, but the Arctic Refuge did have several established goals: provide quality polar bear viewing, minimize threats to visitors and locals, minimize impact to polar bears, and minimize conflicts between tourists and locals (USFWS, 2017). A formal management plan for polar bear viewing in the Kaktovik area of the Arctic Refuge is being formulated and is planned for implementation in the near future. Social science efforts, including those for the current paper, were conducted to help inform this plan. The research in this paper is intended to provide both a better understanding of and ways to promote the positive outcomes of viewing polar bears in Kaktovik, specifically the creation of ambassadors for polar bears and their sensitive Arctic environment. 
EXAMINING PRO-ENVIRONMENTAL OUTCOMES OF LAST CHANCE TOURISM

\section{Visitor Surveys and Study Population}

Surveys were administered on-site in the two Kaktovik hotels, daily, between late-August and early-October 2017. Only tourists who had been on the water viewing polar bears were asked to complete the survey. A census approach to sampling was utilized where attempts were made to intercept as many visitors as possible that had viewed bears out on a boat. Surveying took place at various times throughout the day to intercept both day and overnight visitors. Efforts were taken to only collect one survey from each visitor, and to find and ask all tourists visiting Kaktovik. The survey was available only in English.

\section{Measures}

Surveys were developed to help better understand polar bear tourists and their time in Kaktovik, their attitudes, and the outcomes of their experiences. The survey asked questions on general trip characteristics (i.e., time on water, number of polar bears seen, difference between polar bears seen and expected, trip length, minutes of education, and occurrence of an epiphany) and socio-demographics (i.e., age, education level, home state/country, and travel group size/makeup). Using input from Arctic Refuge staff based on their experiences in Kaktovik and observations of polar bear viewers, a list of important experience elements were created, and visitors were asked to rate the importance of each aspect. Pro-environmental outcomes were measured by examining visitors' intention to participate in pro-environmental and ambassadorship behaviors related to polar bear and the Arctic environment. These measures were based on Skibins and Powell's (2013) scales for measuring connections to wildlife and pro-conservation 
EXAMINING PRO-ENVIRONMENTAL OUTCOMES OF LAST CHANCE TOURISM

actions. Tourists were asked how likely they were to change certain behaviors as a direct result of their experience. Examples of actions are "tell others about the population status of polar bears" and "live in ways to help lessen the warming of the Arctic environment." Also, based on Vining and Merrick's (2012) definition on environmental epiphanies and its stated potential application and importance to public land management, tourists were asked "During your time in the Kaktovik area of the Arctic Refuge did you experience any environmental epiphanies, "aha" moments, or moments when your thinking about conservation or your connection to nature really shifted substantially?"

\section{Data Screening and Set Up}

To address the guiding research questions of this study, the following process occurred. Prior to the completion of various analyses, the data were screened for multivariate nonnormality and outliers in SPSS 24. Specifically, boxplots were utilized to screen data for statistical outliers that fell beyond three interquartile ranges. The results of this analysis indicated 52 respondents were harming model fit, as such these outliers were removed from further analyses (Gagnon, Stone, \& Garst, 2017). Next the data were inspected for missingness, specifically the degree to which responses were complete; 21 respondents did not complete at least $80 \%$ of questions, thereby violating the study protocol, and were removed from the analyses. Next the data were screened for systematic causes of missingness within EQS 6.3 software, utilizing a Full Information Maximum Likelihood (FIML) estimator to detect missing values. As part of this process, the data were screened for multivariate kurtosis (Byrne, 2006), the results of which indicated 3 additional respondents were contributing to nonnormality within the dataset 
EXAMINING PRO-ENVIRONMENTAL OUTCOMES OF LAST CHANCE TOURISM

and were correspondingly removed from further analyses. Next the data were examined for systematic causes of missingness (e.g., Missing Completely At Random, MCAR; Missing Not At Random, MNAR), utilizing Little's test of MCAR (1988) and $p \leq .001$ criterion. The results of this analysis indicate the data were nonsignificant, thus MCAR $\left(\chi^{2}(8228)=8131.227, p=.774\right)$. Next, given evidence of MCAR, missing data were generated utilizing an Expectation Maximization (EM) technique, which is considered mathematically equivalent to FIML. This approach was especially appropriate given the hypotheses and research questions were using non-latent (i.e., composite) techniques.

\section{Analyses}

Analyses were conducted with the remaining 189 questionnaires. First, responses related to visitor sociodemographic variables and general experience elements were analyzed using response frequencies and descriptive statistics. Next, a K-Means cluster

analysis was performed based on the importance of experiential variables separated into 4 subscales (i.e., wildlife, culture, education, and other activities). K-Means clustering is a statistical tool that can be utilized to divide data into $k$ clusters based on similarities and/or differences (Kim \& Yamashita, 2007). Clustering data is used to determine intrinsic groupings within data and maximize similarity within and differences between cluster groupings (Nath, Lee, Chowdhury, \& Chang, 2010; Rendón, Abundez, Arizmendi, \& Quiroz, 2011). Thus K-Means clustering can divide traveler motivations into groups utilizing subscale scores. Internal validity of each subscale's items was confirmed using a reliability assessment and the associated Cronbach's alpha statistic. This assessment verified that each subscale's items could be combined into a composite 
EXAMINING PRO-ENVIRONMENTAL OUTCOMES OF LAST CHANCE TOURISM

score. Composite scores were created for each subscale based on respondents' average answers to a 5-point Likert scale for all related items. Average trip characteristics (i.e., time on water, number of polar bears seen, difference between polar bears seen and expected, trip length, minutes of education, and occurrence of an epiphany) were then analyzed within each cluster group. Though pro-environmental and ambassadorship behaviors were initially measured as two dimensions (polar bears and Arctic environment), a correlation of .92 suggests that construct overlap might be present and there may not be a distinguishing difference to justify uniqueness (Beeco \& Hallo, 2014). Due to this high correlation, behaviors were combined into an overall pro-environmental outcome score. This composite score was created based on responses on a 7-point Likert-type scale to 12 behavioral intention items. Cronbach's alpha helped examine the internal validity of this composite score. The researcher examined descriptive statistics and conducted means testing to examine the pro-environmental outcomes potential per cluster group and for the entire population. Multiple regressions were conducted to examine relationships between the trip characteristics described above and proenvironmental outcomes within cluster groups and overall. Finally, differences in sociodemographic characteristics, importance of experience variables, trip characteristics, and outcomes were compared between cluster groups using ANOVA and Chi-Square Test of Independence. The researcher employed the Durbin-Watson test to check for autocorrelation of the independence of observations. 


\section{RESULTS}

\section{Visitor Profile and Trip Description}

The questionnaire sample indicated that visitors to the Kaktovik area of the Arctic National Wildlife Refuge were mostly middle-aged and older adults $(\mathrm{M}=54.0$ years, $\mathrm{SD}=$ $15.0)$, very well educated ( $73.9 \%$ had bachelor's or post-graduate degrees), and traveling in groups $(\mathrm{M}=4.9$ people, $\mathrm{SD}=5.0)$. The majority of visitors $(71.7 \%)$ originated from the USA. The primary trip purpose for $74.5 \%$ of visitors to the Kaktovik area of the Arctic National Wildlife Refuge was to view polar bears.

Trips to Kaktovik lasted on average 2.2 days $(\mathrm{SD}=1.3)$ with $92.7 \%$ of respondents being first time visitors. A small selection of visitors $(12.6 \%)$ have viewed polar bears in other locations, including Svalbard and Churchill. Visitors spent an average of 5.1 hours $(\mathrm{SD}=4.1)$ on the water during their visit and saw an average of 23 polar bears $(\mathrm{SD}=14.4)$ which is $33 \%$ more than what they expected to see. Visitors reported that having their viewing activities not impact or disturb polar bears was the thing they liked most about their time on the water (30.7\%) and bad weather (e.g., wind, rain, cold, snow) was their least favorite thing (42.4\%). Approximately 50\% of visitors felt they were viewing polar bears in a remote and natural setting. Elements of the experience most important to visitors, on a five-point Likert scale, were viewing polar bears while on the water $(\mathrm{M}=4.7, \mathrm{SD}=0.8)$, not disturbing or impacting polar bears while viewing them $(M=4.7, S D=0.8)$, viewing bears without windows obstructing the view $(\mathrm{M}=4.5, \mathrm{SD}=0.9)$, and polar bear viewing not disturbing or impacting the local Native 
EXAMINING PRO-ENVIRONMENTAL OUTCOMES OF LAST CHANCE TOURISM

Alaskan community $(\mathrm{M}=4.5, \mathrm{SD}=1.0)$. Visitors on average spent $16.6(\mathrm{SD}=16.4)$

minutes being educated by either Refuge staff or their tour operator.

Visitor Motivation Groups and Group Differences

Aspects of the polar bear viewing experience were separated into 4 categories determined conceptually from survey items (e.g., wildlife, culture, education, and other activities). The survey items that made up the scales were assessed for correlation and reliability to see if they consistently reflect each construct. Each construct's reliability was acceptable, with the wildlife subscale made of 9 items $(\alpha=.789)$, the culture subscale of 3 items $(\alpha=.635)$, the education subscale of 3 items $(\alpha=.859)$, and the other activities subscale of 3 items $(\alpha=.748)$. Participant responses were then made into composite scores for each subscale to be used in the K-Means cluster analysis.

The K-Means cluster analysis resulted in three cluster groups based on composite score responses to each of the above-mentioned subscales (Figure 3). Three cluster groups were chosen over other cluster solutions following expert evaluation of low iterations, higher F-values and related ANOVA statistical tests. Based on overall composite scores, group 1 (58.7\% of participants) found all aspects of the polar bear viewing experience important $(M>3)$, group 2 (3.2\% of participants) found no aspects of the experience important $(\mathrm{M}<3)$, and group 3 (38.1\% of participants) found aspects related to wildlife of primary importance $(\mathrm{M}=4.4)$ with culture, and education of lesser importance (M approximately 3 or less).

Items used in each subscale composite were also analyzed separately by group (Table 1). Groups 1 and 3 were similar in their wildlife viewing composite scores. Their 
EXAMINING PRO-ENVIRONMENTAL OUTCOMES OF LAST CHANCE TOURISM

highest ranked wildlife related element was viewing polar bears while on the water, with Group 2 differing significantly by ranking it as an unimportant element $[F(2,186)=105.61, p<0.001]$. All cluster groups differed in their cultural interactions $[\mathrm{F}(2,186)=121.55, \mathrm{p}<0.001]$ and educational opportunities composite $[\mathrm{F}(2.186)=140.10$, $\mathrm{p}<0.001]$ and all corresponding elements. Group 1 ranked most cultural elements as important $(\mathrm{M}>4)$, Group 2 ranked all elements as unimportant $(\mathrm{M}<2)$ and Group 3 ranked most as moderately important $(\mathrm{M} \approx 3.5)$. For elements related to education, Group 1 found all elements important $(M>4)$, Group 2 found all unimportant $(M<2)$, and Group 3 rated them as moderately important $(M \approx 3.5)$. Groups 2 and 3 were significantly different from Group 1 for their additional activities composite $[\mathrm{F}(2,186)=82.57, \mathrm{p}<0.001]$. Group 1 ranked additional activity elements as moderately important $(\mathrm{M} \approx 3.5)$ with Groups 2 and 3 finding them less important $(\mathrm{M}<3)$.

Groups sociodemographic characteristics were also examined (Table 2). However, no statistical differences were found between groups. Differences between groups were assessed on key trip characteristics (Table 3). There was a significant difference between cluster groups for total time educated $[\mathrm{F}(2,186)=3.75, \mathrm{p}=.025]$. Groups 1 and 3 differed significantly at $p<.05$ with Group 1 experiencing an average of 19.3 minutes of education and Group 3 experiencing 12.7 minutes. The occurrence of an epiphany also differed significantly $\left[\mathrm{X}^{2}(2, \mathrm{~N}=158)=12.99, \mathrm{p}=.002\right]$. There was significant a difference between Groups 1 and 3 with $34.2 \%$ of Group 1 and $12.5 \%$ in Group 3 visitors reporting the occurrence of an epiphany. 
EXAMINING PRO-ENVIRONMENTAL OUTCOMES OF LAST CHANCE TOURISM

\section{Pro-environmental Outcomes}

Pro-environmental outcomes were measured with a composite score for overall behavioral intention $(\alpha=.957)$. The study population as a whole was analyzed for potential gains in pro-environmental outcomes (Table 4). Visitors reported an increase in intention to participate in all pro-environmental outcomes measured. Cluster groups were also analyzed individually for pro-environmental outcomes potential (Table 4). There were significant differences between cluster groups for overall outcomes $[F(2,186)=20.15, p<0.001]$. Groups 1 and 3 differed significantly for the overall composite score and individual actions $(\mathrm{p}<0.05)$.

A multiple linear regression was conducted to predict if certain experience elements significantly predicted participants' ratings of future behavioral intention overall (Table 5). This analysis indicated that three predictors explained $48.2 \%$ of the variance $[F(6,112)=5.650, p<.001]$. Total minutes educated and the occurrence of an epiphany had significant positive regression weights, indicating visitors with more educational interactions and who experienced an epiphany reported higher likelihood of intention for actions overall, after controlling for the other variables in the model. Number of bears seen has a significant negative weight, indicating that after accounting for minutes educated and the occurrence or absence of epiphanies, visitors seeing more bears were expected to report a lower overall behavioral intention.

Multiple regressions were also run by cluster group to test if cluster membership lead to different experience elements predicting the rating of overall outcomes (Table 5). This analysis for Group 1 indicated that one predictor explained $47.7 \%$ of the variance 
$[F(6,60)=2.953, p<.014]$. The occurrence of an epiphany has a significantly positive influence on reported overall behavioral intention. Due to insufficient sample size for Group 2, a linear regression was unable to be performed. The model for Group 3 was marginally not significant $[\mathrm{F}(6,40)=2.202, \mathrm{p}=.063]$. However, when trip characteristics were looked at individually, total minutes educated had significant positive influence on overall outcomes $(\mathrm{p}<.05)$. 
EXAMINING PRO-ENVIRONMENTAL OUTCOMES OF LAST CHANCE TOURISM

\section{DISCUSSION}

The purposes of this study were to describe Arctic polar bear tourists and their experience in Kaktovik, develop a typology based on trip motivations and describe those groups, find how likely visitors are to become ambassadors based on their motivations, and investigate the influence of various trip elements on reported likelihood to participate in pro-environmental or ambassadorship behaviors.

The majority of visitors to the Kaktovik area of the Arctic National Wildlife Refuge are largely middle aged and highly educated which is consistent with the findings of studies on similar wildlife viewing experiences (Montage et al., 2005; Powell et al., 2012; Powell et al., 2008; Wight, 2001). Three groups of visitors to the Kaktovik area were identified based on common motivations for visiting by utilizing the importance ranking of various aspects of the trip experience. Group 1 may be labeled 'Holistic Viewers', as all elements of the experience were of relatively equal importance to them. Even though viewing polar bears was their main reason for visiting, along with Groups 2 and 3, a full experience was important to Holistic Viewers. In addition to wildlife viewing being important, so were educational opportunities, cultural interaction, and additional activities. Holistic Viewers, though polar bears brought them there, wanted to take full advantage of everything Kaktovik had to offer. Group 2 may be labeled as 'No Expectations.' Their lack of expectations could come from 3 out of 6 members being a part of a larger organized tour group around Alaska. Since Kaktovik was just a small part of a broader experience, these guests could have had different motivations for booking their broader trip and therefore no elements of the Kaktovik experience were of great 
EXAMINING PRO-ENVIRONMENTAL OUTCOMES OF LAST CHANCE TOURISM

importance. Though cluster membership was low for this group, all participant viewpoints are important and should be considered. Removing feedback, because of low numbers, does not result in a complete examination of the types of visitors to Kaktovik, and this group could become more prevalent as use changes or increases at the site. Group 3 may be labeled 'Wildlife Enthusiasts.' Though cultural interactions and education opportunities were of mid-level importance, their highest priority was viewing polar bears.

Similar to the findings of Kruger, Viljoen, and Saayman (2017), this shows that visitors to such experiences cannot all be treated the same as there are distinct differences found between clusters. All three clusters, though differing in motivational factors, were similar on various demographic characteristics; this does not align with a similar study by Lindsay, Alexander, and Mills (2007), which found visitor preferences differed based on respondents' characteristics. A study out of Thailand clustered visitors based on various motivations and found 5 cluster groups when motivation was based on activity and three cluster groups when motivation was based on broader trip characteristics (Hvenegaard, 2002). Visitors studied by Powell et al. (2008), ranked viewing wildlife as a top motivation for participation; this is similar to the main motivations of Groups 1 and 3 in the current study, where wildlife related experiential elements ranked as most important. Unlike LCT visitors studied by Powell et al. (2008), who ranked education motivations lower down, Holistic Viewers and Wildlife Enthusiasts found educational elements either $1^{\text {st }}$ or $2^{\text {nd }}$ in importance. 
EXAMINING PRO-ENVIRONMENTAL OUTCOMES OF LAST CHANCE TOURISM

Participation in a boat-based polar bear viewing experience in Kaktovik, Alaska led to a reported increase of pro-environmental outcomes in both the study population over all and in individual cluster groups. The findings show that an LCT experience can increase participants' intentions to carry out pro-environmental and ambassadorship behaviors. Though studies have reported that visitors to such experiences are already 'converted' to support pro-environmental outcomes and knowledge increases or behavior changes are susceptible to a 'ceiling effect', there is still potential for positive growth in this setting (Beaumont, 2001; Caplow, 2018; Powell, Kellert, \& Ham, 2009). This aligns with other studies showing that ambassadorship creation is a positive outcome of the LCT experience (Eijalaar et al., 2010; Lemelin et al., 2010). In addition to strictly LCT experiences, Orams (1997) found that direct environmental interactions in general can lead to positive attitude and behavior formation related to the environment. This also aligns with a study out of Nigeria National Parks showing that those who participate in ecotourism experiences have higher favorable environmentally based attitudes (Ogunjinmi, 2016). However, these findings counter those of Beaumont (2001) who identified a potential ceiling effect in visitors to ecotourism destinations like the Kaktovik area of the Arctic Refuge, which limits improvements in their ambassadorship or proenvironmental attitudes. Dawson et al. (2011) would agree that visitors to remote, sensitive environments have very little concern for the environment even after visiting. These results show that every experience is unique and will therefore result in unique outcomes. Since all experiences are different, it is important to look at what elements of a nature experience might significantly influence pro-environmental outcomes. 
EXAMINING PRO-ENVIRONMENTAL OUTCOMES OF LAST CHANCE TOURISM

To help better understand how these changes occur, multiple linear regression analyses were used to assess the impact of various trip characteristics on reported change in pro-environmental behaviors of the study population. Figure 4 shows these variables within an adapted interaction theory model (Skibins et al., 2016). The results suggest that certain experience characteristics were important for predicting changes in behavior intentions. Experience characteristics that positively predicted increased behavioral intentions were total minutes educated and the occurrence of epiphanies. These findings are consistent with other studies that found education to have a positive impact on environmental attitudes, behaviors, and knowledge (Ballantyne et al., 2007; Eijalaar et al., 2010; Hungerford \& Volk, 1990; Orams, 1997). Pooley and O’Connor (2002) found that for an experience to be most impactful, in addition to education, a visitors' emotions and beliefs must be stimulated, which aligns with the finding that increased occurrence of epiphanies results in higher pro-environmental outcomes.

About a third of those visiting Kaktovik report experiencing an environmental epiphany. This portion of visitors seem substantial given the high levels of education, socioeconomic status, and likely environmental attitudes associated with these visitors. This quantification of visitors who experienced an epiphany helps address the need expressed by Vining and Merrick (2012) to quantify the occurrence of epiphanies in environmental settings and experiences. Epiphanies in the context of this study show a direct linkage to pro-environmental behaviors. This aligns with studies that found place attachment, or an emotional connection to a location, could predict an individual's pro- 
EXAMINING PRO-ENVIRONMENTAL OUTCOMES OF LAST CHANCE TOURISM

environment intentions related to that location (Halpenny, 2010; Scannell \& Gifford, 2010).

The reported change in pro-environmental and ambassadorship behavior for the study population as a whole was also impacted by the number of bears seen. However, for this trip characteristic, the more polar bears that one saw resulted in a negative change to behavioral intention. This disputes many studies in wildlife tourism settings that found an increase in viewing opportunities of charismatic megafauna such as wolves, Africa's "Big 5", grizzly bears, caribou and similar animals provided an increase in proenvironmental outcomes, including attitudes and behaviors, and overall conservation support (Skibins, Hallo, Sharp, \& Manning, 2012; Skibins, Powell, \& Hallo, 2016; Skibins, Powell, \& Hallo, 2013). This finding could be due to the fact that polar bears are a threatened species and have become an icon of climate change's impact on melting the Arctic ice. A study by Born (2018) analyzed all feature climate change articles and their accompanying pictures that appeared in National Geographic from 1992-2012 and found that polar bears were the animal shown most frequently. Though not reported on in this study, a visitor interviewed in Kaktovik revealed their main reason for traveling was to see for themselves the environmental situation and to determine "what's right and what's wrong about what they [media] say." This idea that polar bears are threatened and are the 'poster child' of global warming and Arctic sea ice loss would imply that seeing polar bears in the wild is a rare event. In addition to low numbers, it would be unexpected to find one in good physical condition. However, upon arrival, visitors are met with a large congregation of well-fed polar bears due to the island's anthropogenic 
EXAMINING PRO-ENVIRONMENTAL OUTCOMES OF LAST CHANCE TOURISM

food source- whale remains. This seems counterintuitive and could be influencing the finding that seeing more polar bears does not result in increased pro-environmental and ambassadorship behavior intentions, but rather has the opposite effect. Since availability is a heuristic that people utilize to make judgements, visitors could be placing a larger value on the visual in front of them (large numbers of bears) than any information about the overall status of the Arctic environment (Tversky, \& Kahneman, 1974).

Characteristics related to time immersed in the LCT experience, time on water and length of stay were not found to significantly influence ambassadorship outcomes. This diverges from other studies that found time in an environmentally based experience greatly influences positive outcomes. For example, Bogner (1998) found that a 5-day outdoor program elicited more favorable shifts in actual and intended behavior over a one-day program. Dearden, Bennett, and Rollins (2007) discovered that divers on day excursion in the Philippines were less likely to realize their environmental impact than divers on longer trips. This divergence could be due to the main experiential elements occurring relatively quickly once a visitor arrives in Kaktovik. One is immersed immediately in the local Inupiat culture and bears can be seen through spotting scopes from hotel lobbies. Unlike safaris where it can take days to find iconic species, you can see a polar bear within minutes of arriving in Kaktovik. High day visitation in Kaktovik also supports the possibilities and occurrences of 'instant gratification' in the experience, making longer stays less influential on positive outcomes.

These differences from available literature overall could be based in interactional theory. Since the basis of interaction theory is that behavior is influenced by the 
EXAMINING PRO-ENVIRONMENTAL OUTCOMES OF LAST CHANCE TOURISM

relationship between an individual and the physical and social environments, having unique outcomes from a truly globally unique experience in Kaktovik would match the theory (Skibins, Powell, \& Hallo, 2013). It speaks to the complexity of such experiences and the interactional elements that make them up. Since Kaktovik is so singular in its interactions between viewers, the social, and physical environments, distinct outcomes as compared to the literature are not surprising.

Differences were found between Holistic Viewers and Wildlife Enthusiasts for pro-environmental outcomes. This is the first study, to the authors' knowledge, that relates motivations to pro-environmental outcomes. Holistic Viewers ranked significantly higher on intentions for all outcomes over Wildlife Enthusiasts. For the Holistic Viewers, the occurrence of an epiphany influenced the overall composite score. Wildlife Enthusiasts' intentions were found to only be influenced by total minutes educated. These findings could be due to their motivational differences. Holistic Viewers, as previously discussed, are those that all elements of the trip are important. They may want to take advantage of all opportunities available in Kaktovik. This motivation to experience all that is offered could open up the opportunity for experiencing an emotional connection to the location, which leads to the occurrence of epiphanies. Since viewing polar bears was not their singular motivation, seeing more polar bears may decrease their intention to partake in polar bear related outcomes. Opposite of that are the Wildlife Viewers, for whom seeing more bears did not impact their pro-environmental outcomes. This is most likely due to viewing polar bears being their singular motivation. This motivation may lead to a focused experience leaving less 
EXAMINING PRO-ENVIRONMENTAL OUTCOMES OF LAST CHANCE TOURISM

opportunity for emotional connections to be formed leading to fewer epiphanies. Total time educated did influence reported pro-environmental outcomes for Wildlife Enthusiasts. This could be related to a focused desire to learn more about the status of a species they had traveled great distances to specifically see. Since educational topics were centered on their primary motivation, polar bears and their environment, this may have led these visitors to appreciate educational time more than seeking a holistic experience.

\section{Management Implications}

Based on the results of this study, there are many implications that might be of interest and use to Arctic Refuge management. Tourist typology information allows managers to address different motivations, experiences, and impacts of varying tourist types. These different types of tourists, though visiting to view polar bears, are all expecting a different experience through their distinct motivations. This shows managers that their visitors are not homogenous, so the experience cannot be either. These findings also suggest that USFWS employees and registered tour operators have the opportunity to adjust certain trip characteristics to help increase the reported intentions of visitors to participate in pro-environmental and ambassadorship behaviors after their trip.

Possible adjustments include improvements to on-site interpretation to provide more consistent educational opportunities for guests to develop a deeper understanding of the current status of polar bears. Education for visitors from Refuge staff was the responsibility of a 3 USFWS volunteers and one staff member visiting for rotations in the 2016 and 2017 viewing seasons. This educational offering consisted of USFWS affiliates 
EXAMINING PRO-ENVIRONMENTAL OUTCOMES OF LAST CHANCE TOURISM

going to the two lodging locations to intercept visitors. The delivery was often inconsistent and interrupted due to loud and distracting environments and visitors that were often going to or finishing meals or waiting to be picked up for a polar bear viewing excursion. In addition to these non-conducive conditions, supplemental data, not utilized in the main analyses, showed that $41.0 \%$ of visitors reported no educational interaction with Refuge staff and $51.2 \%$ reported no such interactions with their guides. Changes to or increases in education, more interaction with Refuge staff and infrastructure committed to cultural and environmental education were the highest reported requests of visitors. To help combat this inconsistency and the increase in visitation, a full time, visitor outreach staff member was added in the 2018 season. Not until further research is conducted will management find if staffing is enough to combat this inconsistency.

This inconsistent educational component could be one possible reason seeing an increase in polar bears resulted in a decrease in pro-environmental outcomes. Without consistent and informative educational opportunities, visitors are not learning about the complex relationship between the town of Kaktovik and the polar bears. When they view large congregations of polar bears, they are possibly seeing a situation that they perceive does not need to be fixed. Educational components would fill this knowledge gap by emphasizing more that the reason polar bears are on Barter Island is because their ice is too far away during that part of the year. Since their ice is too far away, so is their prime food source, seal. This forces polar bears to seek out other unnatural food sources, like the one provided by the whale. Though polar bears have always been an occasional visitor for Barter Island, not until 2002, a year of record low summer ice extent, did the 
EXAMINING PRO-ENVIRONMENTAL OUTCOMES OF LAST CHANCE TOURISM

population draw scientific interest (Serreze et al., 2003; USFWS, 2012). Based on visitor comments not reported in this paper, some visitors see the large number of polar bears around Barter Island as a sign they are doing well, not that their prime ecosystem is out of reach. These results justify the need for infrastructure and staffing resources to support education on site.

In addition to the education itself, learning experiences that speak to visitors' emotions, in addition to giving information, tend to have more success. Since the occurrence of an epiphany was the largest influencer on pro-environmental outcomes, increasing emotional connections through intellectual routes could help interpretation programing be more impactful in a LCT setting (Ham \& Weiler, 2002). Creating experiences that educate and influence emotions and beliefs are more likely to impact visitor attitudes and change behaviors than those that just educate (Pooley \& O'Connor, 2000). Given this information, management should allow for opportunities that encourage visitors to reflect on their experience and new knowledge. This time has been found to elicit an emotional connection, which can promote the occurrence of epiphanies, and prompt environmental awareness and intention to act (Hughes, 2013).

Emotional gains could also be created by setting visitors up for a rare and novel experience. Consumer behavior studies show that people place high interest and value in rarity (Koford \& Tschoegl, 1998; Weiss, 2004). Clayton et al. (2016) found that certain dimensions of an experience can have a greater impact on emotional connections with nature. Appreciative experiences tend to be more likely to lead to conservation outcomes over consumptive practices, as well as self-directed experiences where visitors have a 
EXAMINING PRO-ENVIRONMENTAL OUTCOMES OF LAST CHANCE TOURISM

greater sense of control (Clayton et al., 2016). After examining characteristics of an environmental epiphany, Storie and Vining (2018) recommend managers encourage storytelling from both staff and visitors about emotional or epiphanic experiences, provide a variety of experiences in the environment, and cater to diverse audiences. Storie and Vining (2018) also categorize epiphanies into 5 types: aesthetic, intellectual, realizations, awakening, and connectedness; this diverse categorization allows for many characteristics of the experience to influence epiphanies such as beauty of the natural landscape, oneness or solitude, and intellectual insights. The complexity of epiphanies requires additional research to further develop management techniques to encourage their occurrence.

Overall, this LCT destination has a unique opportunity to break the 'doom', 'gloom' LCT cycle. The Kaktovik area of the Arctic Refuge has substantial potential, with intentional and cooperative management, to be a LCT destination that remains small and sustainable due to its location, cost, and current lodging restraints. It is also a destination that can be feasibly managed in a way to protect onsite resources, experiences, and increase pro-environmental outcomes through the implementation of changes with locals' and managers' control. Though locals and managers have no control over large scale variables, such as climate change, they can control smaller variables to lessen the impact of the tourism experience.

\section{Limitations}

As noted in the data preparation section, 76 respondents were removed from the data set due to highly incomplete responses and/or evidence of nonnormality (e.g., 
EXAMINING PRO-ENVIRONMENTAL OUTCOMES OF LAST CHANCE TOURISM

"pencil whipping"). The combination of these issues calls into question why $28.7 \%$ of the sample had so many challenges correctly completing the questionnaire. Some potential explanations for this could be the overall length of the questionnaire (8 pages front and back, 140 items), it being available only in English, and the difficulty with fitting survey efforts into day visitors' onsite experience. Behavioral changes were selfreported and do not reflect actual change of behavior upon completion of their trip, so even though reported intention was high, measure of actual behavior change was not included in this study. Another limitation relates to challenges with implementation where some program stakeholders (e.g., tour operators) were not fully committed to the project and may have unduly influenced participation quality within questionnaires.

\section{Conclusion}

With tourism to the Kaktovik areas of the Arctic National Wildlife Refuge increasing exponentially, increasing pro-environmental outcomes will assist in preserving the experience. Protection of the Arctic environment and sustaining a polar bear tourism experience into the future relies on identifying the factors that lead to positive outcomes that can help mitigate the negative impacts of visitation to such sensitive environments. By combining increased interpretation opportunities with adjusted trip characteristics, USFWS can create an experience that leads to an increase in positive environmental behavioral intentions. The results provide insight into the potential pro-environmental outcomes of a LCT experience.

Future research in this area should involve increased stakeholder participation to ensure greater buy-in to the research project and goals to serve the Artic community 
stakeholders. Further research would also reveal if the additional staffing would result in an increase in major change to the reported educational experience and proenvironmental outcomes. Outside of Kaktovik, further research should continue to examine the relationship between trip elements and pro-environmental outcomes and the additional influence of visitor motivations. This additional research can help transfer the findings for use in other LCT experiences, as all experiences are unique and will potentially result in different influential trip characteristics.

\section{Funding Disclaimer}

This research was supported by the United States Fish and Wildlife Service. The contents of this thesis are solely the responsibility of the authors and do not necessarily represent the official views of the United States Fish and Wildlife Service. The United States Fish and Wildlife Service, though involved in the study design, was not involved in analysis of data or the development of this paper. 


\section{FIGURES AND TABLES}

Figure 1

Polar bear tourism locations in the Arctic with subpopulation range overlay

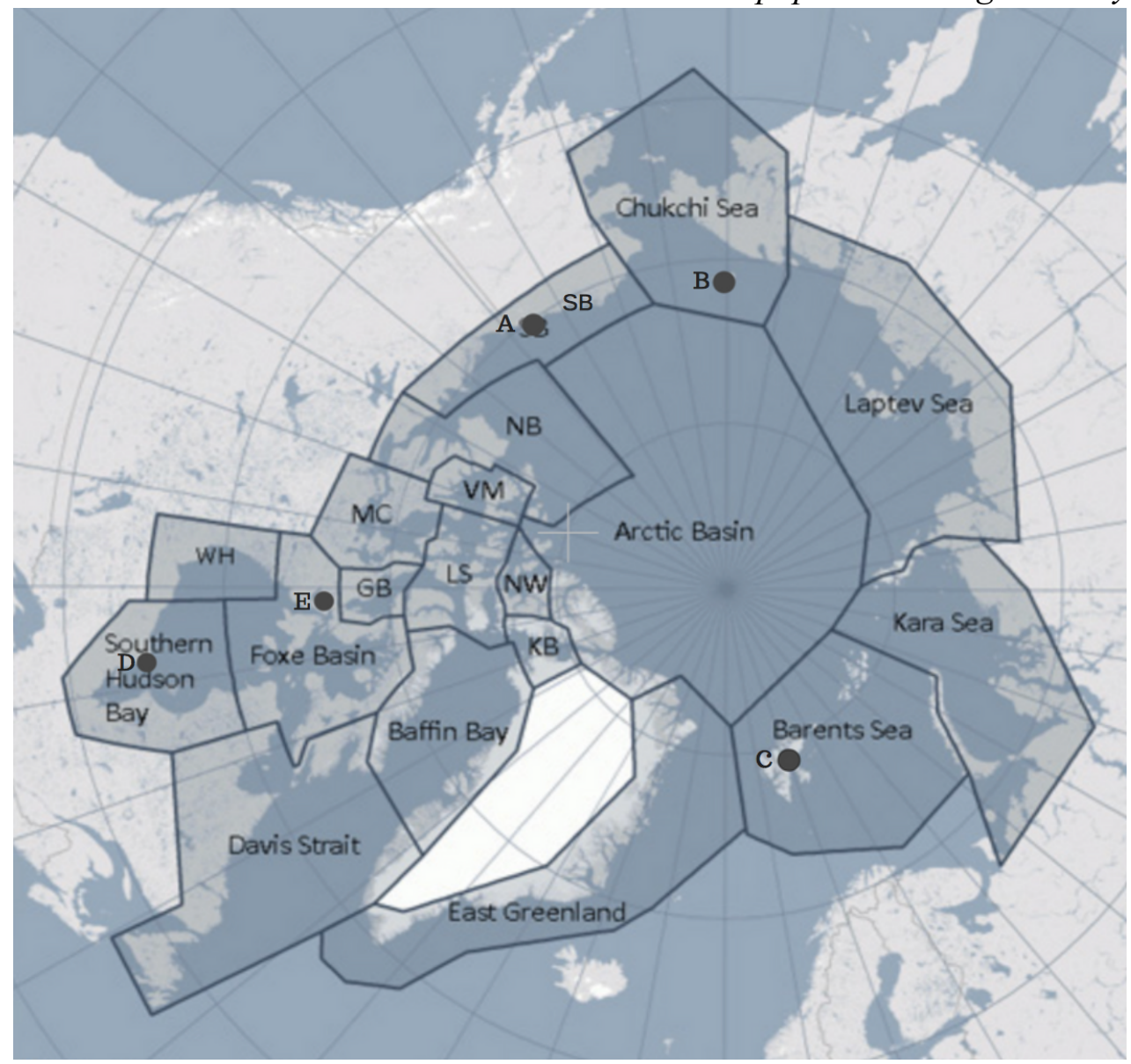

A: Kaktovik, Alaska, USA

B: Wrangel Island Zapovednik, Russia

C: Svalbard Archipelago, Norway

D: Churchill, Ontario, Canada

E: Ukkusiksalik National Park, Nunavut, Canada

Note: Subpopulations include- Southern Beaufort Sea (SB), Chukchi Sea, Laptev Sea, Kara Sea, Barents Sea, East Greenland, Northern Beaufort (NB), Kane Basin (KB), Norwegian Bay (NW), Lancaster Sound (LS), Gulf of Boothia (GB), M'Clintock Channel (MC), Viscount Melville Sound (VM), Baffin Bay, Davis Strait, Foxe Basin, Western Hudson Bay (WH), Southern Hudson Bay and the Arctic Basin (AB) adapted from (USFWS, 2016). 
Figure 2

Model of last chance tourism (Dawson et al., 2010)

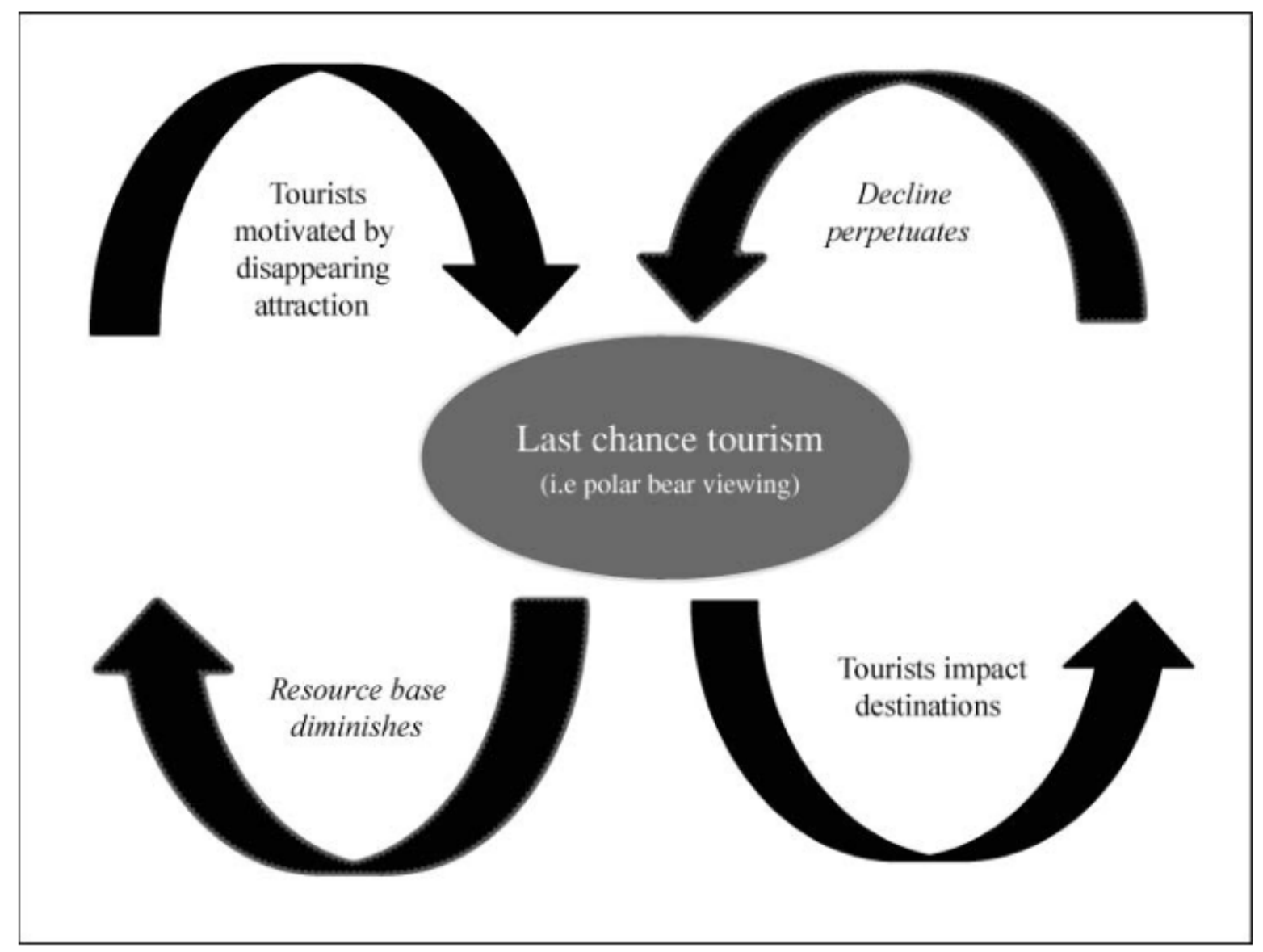


EXAMINING PRO-ENVIRONMENTAL OUTCOMES OF LAST CHANCE TOURISM

Figure 3

Importance of various experiential element composite means by cluster groups

\section{Importance Composite Means by Cluster Groups}

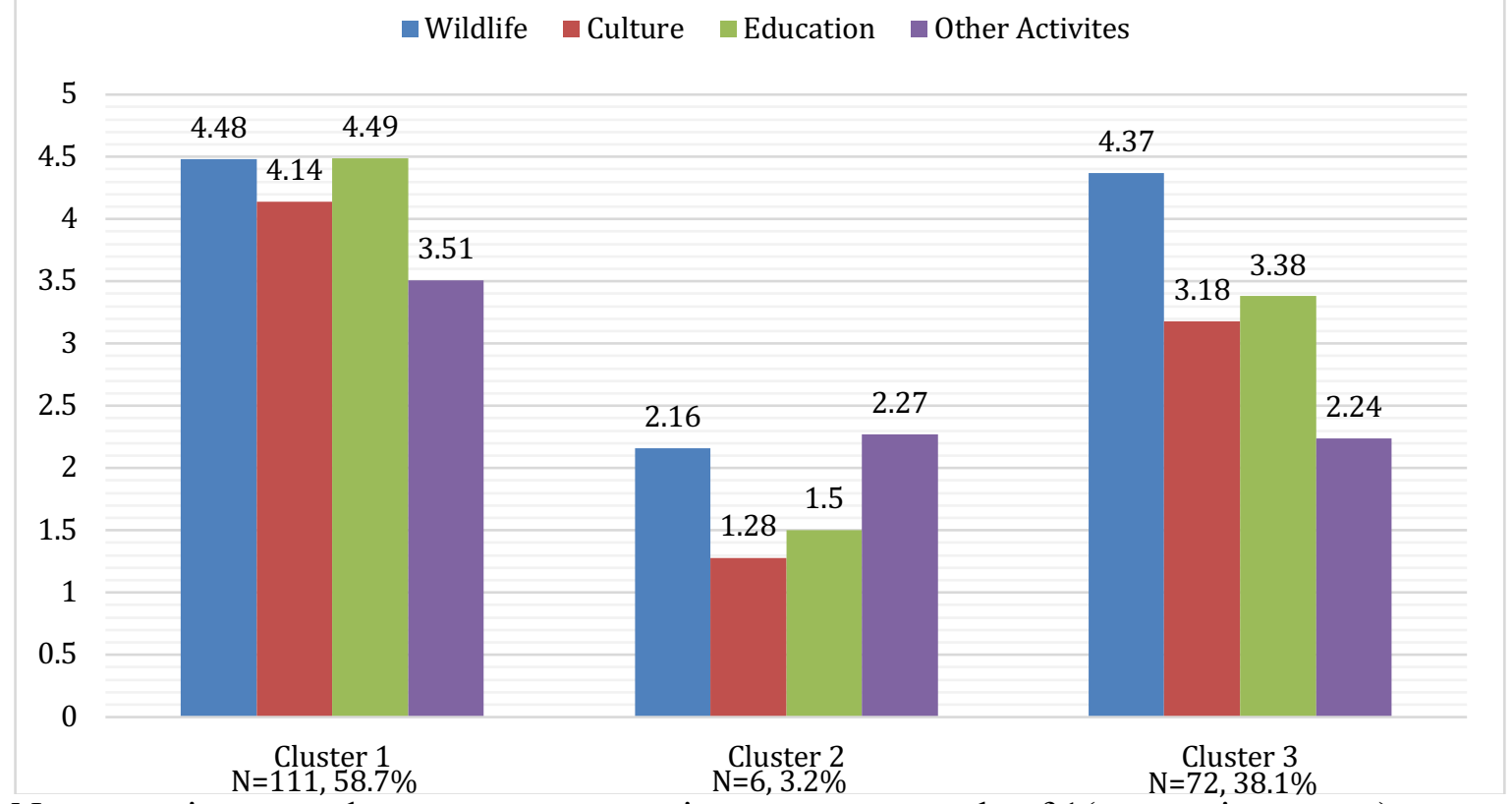

Note: $y$-axis scores denote mean composite scores on a scale of 1(very unimportant) to 5(very important 
Figure 4

Interactional theory framework applied to Kaktovik viewing characteristics adapted from (Skibins et al, 2016)

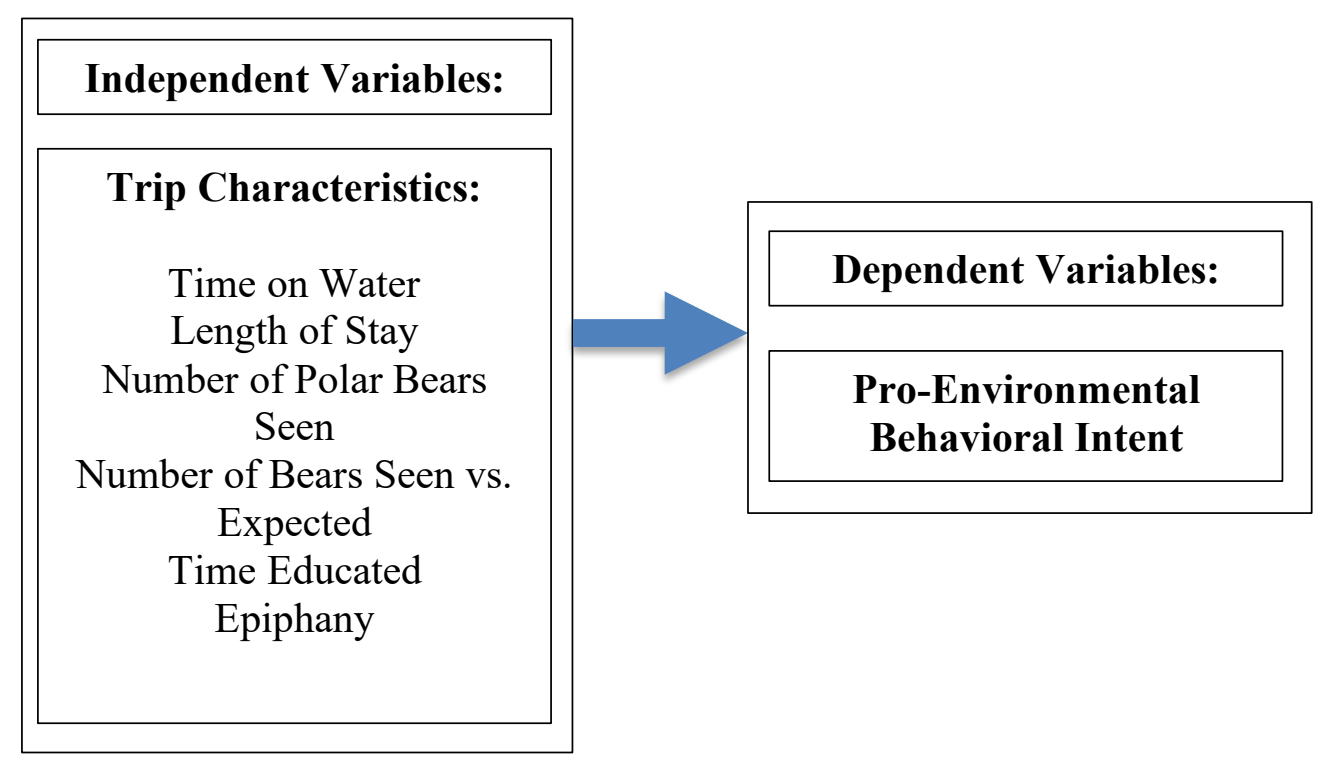


Table 1

Importance of various polar bear viewing experiential elements overall and by cluster group

\begin{tabular}{|c|c|c|c|c|c|}
\hline Experiential Elements & $\begin{array}{c}\text { Study } \\
\text { Populati } \\
\text { on }\end{array}$ & Cluster 1 & Cluster 2 & Cluster 3 & $\mathrm{~F}$ \\
\hline Wildlife Viewing Composite $(\alpha=.789)$ & $4.4(0.6)$ & $4.5^{\mathrm{a}}(0.4)$ & $2.2^{\mathrm{b}}(0.9)$ & $4.4^{\mathrm{a}}(0.4)$ & $* * 92.12$ \\
\hline Viewing polar bears while on the water & $4.7(0.7)$ & $4.9^{\mathrm{a}}(0.4)$ & $1.8^{\mathrm{b}}(1.6)$ & $4.8^{\mathrm{a}}(0.51)$ & $* * 105.61$ \\
\hline Viewing polar bears while on land & $3.7(1.2)$ & $3.8^{\mathrm{a}}(1.1)$ & $2.5^{\mathrm{b}}(1.6)$ & $3.7^{\mathrm{ab}}(1.3)$ & $* 4.12$ \\
\hline Viewing polar bears in a remote, primitive setting & $4.5(0.9)$ & $4.7^{\mathrm{a}}(0.6)$ & $1.7^{\mathrm{b}}(1.6)$ & $4.5^{\mathrm{a}}(0.8)$ & $* * 48.45$ \\
\hline Viewing polar bears without windows to obstruct your view & $4.6(0.8)$ & $4.6^{\mathrm{a}}(0.7)$ & $2.0^{\mathrm{b}}(1.6)$ & $4.7^{\mathrm{a}}(0.6)$ & $* * 42.36$ \\
\hline Viewing polar bears without other boats obstructing your view & $4.5(0.9)$ & $4.6^{\mathrm{a}}(0.7)$ & $2.0^{\mathrm{b}}(1.8)$ & $4.5^{\mathrm{a}}(0.8)$ & **35.34 \\
\hline Viewing polar bears from a safe distance & $4.4(0.9)$ & $4.6^{\mathrm{a}}(0.7)$ & $1.5^{\mathrm{b}}(0.8)$ & $4.4^{\mathrm{a}}(0.8)$ & $* * 49.93$ \\
\hline Viewing polar bears up close & $4.3(1.0)$ & $4.3^{\mathrm{a}}(1.0)$ & $2.3^{\mathrm{b}}(1.8)$ & $4.4^{\mathrm{a}}(0.8)$ & $* * 13.47$ \\
\hline Viewing polar bears from a small boat & $4.0(1.0)$ & $4.2^{\mathrm{a}}(0.9)$ & $2.3^{\mathrm{b}}(1.5)$ & $3.9^{\mathrm{a}}(1.0)$ & $* * 11.16$ \\
\hline Photographing polar bears & $4.5(0.9)$ & $4.6^{\mathrm{a}}(0.9)$ & $3.3^{\mathrm{b}}(1.9)$ & $4.5^{\mathrm{a}}(0.9)$ & $* 5.52$ \\
\hline Cultural Interactions Composite $(\alpha=.635)$ & $3.7(0.8)$ & $4.1^{\mathrm{a}}(0.5)$ & $1.3^{\mathrm{b}}(0.7)$ & $3.2^{\mathrm{c}}(0.6)$ & $* * 121.55$ \\
\hline Having a local guide who is a resident of Kaktovik & $4.3(1.0)$ & $4.7^{\mathrm{a}}(0.6)$ & $1.5^{\mathrm{b}}(1.2)$ & $3.8^{\mathrm{c}}(1.1)$ & $* * 56.75$ \\
\hline $\begin{array}{l}\text { Interacting with and learning about the local Native Alaskan } \\
\text { community }\end{array}$ & $3.8(1.0)$ & $4.3^{\mathrm{a}}(0.7)$ & $1.2^{\mathrm{b}}(0.4)$ & $3.3^{\mathrm{c}}(0.8)$ & $* * 83.46$ \\
\hline Seeing subsistence hunting/whaling activities & $3.0(1.3)$ & $3.5^{\mathrm{a}}(1.2)$ & $1.2^{\mathrm{b}}(0.4)$ & $2.5^{\mathrm{c}}(1.2)$ & $* * 26.18$ \\
\hline Educational Opportunities Composite $(\alpha=.859)$ & $4.0(0.9)$ & $4.5^{\mathrm{a}}(0.5)$ & $1.5^{\mathrm{b}}(0.7)$ & $3.4^{\mathrm{c}}(0.7)$ & $* * 140.10$ \\
\hline Learning science-based information about polar bears & $4.0(1.0)$ & $4.5^{\mathrm{a}}(0.5)$ & $1.3^{\mathrm{b}}(0.8)$ & $3.5^{\mathrm{c}}(0.9)$ & $* * 91.37$ \\
\hline Learning Native Alaskan-based knowledge about polar bears & $4.0(1.0)$ & $4.5^{\mathrm{a}}(0.6)$ & $1.2^{\mathrm{b}}(0.4)$ & $3.4^{\mathrm{c}}(0.8)$ & $* * 115.30$ \\
\hline $\begin{array}{l}\text { Learning or seeing the effects of a warming Arctic environment } \\
\text { on polar bears }\end{array}$ & $3.9(1.1)$ & $4.5^{\mathrm{a}}(0.7)$ & $2.0^{\mathrm{b}}(1.6)$ & $3.2^{\mathrm{c}}(1.1)$ & $* * 61.20$ \\
\hline Additional Activities Composite $(\alpha=.748)$ & $3.0(0.9)$ & $3.5^{\mathrm{a}}(0.6)$ & $2.3^{\mathrm{b}}(0.7)$ & $2.2^{\mathrm{b}}(0.7)$ & $* * 82.57$ \\
\hline Hiking/walking around Kaktovik or Barter Island & $3.0(1.2)$ & $3.5^{\mathrm{a}}(1.0)$ & $1.8^{\mathrm{b}}(1.0)$ & $2.3^{\mathrm{b}}(1.0)$ & $* * 37.55$ \\
\hline Taking a driving tour around Kaktovik or Barter Island & $2.9(1.1)$ & $3.3^{\mathrm{a}}(1.0)$ & $2.8^{\mathrm{ab}}(1.5)$ & $2.1^{\mathrm{b}}(0.8)$ & $* * 37.35$ \\
\hline Interacting with Refuge staff & $3.1(1.1)$ & $3.7^{\mathrm{a}}(0.8)$ & $2.2^{\mathrm{b}}(1.2)$ & $2.4^{\mathrm{b}}(0.9)$ & $* * 59.45$ \\
\hline
\end{tabular}

Note: Mean (standard deviation); scores on a scale of 1(very unimportant) to 5(very important); different superscripts within a row indicate significance at $p<.05$ between clusters; $F=$ F-value, ${ }^{* *} p<.001 ;{ }^{*} \mathrm{p}<.05$ 
EXAMINING PRO-ENVIRONMENTAL OUTCOMES OF LAST CHANCE TOURISM

Table 2

Demographic characteristics overall and by cluster groups

\begin{tabular}{|c|c|c|c|c|c|c|}
\hline Demographic Characteristic & Study Population & Cluster 1 & Cluster 2 & Cluster 3 & $\mathrm{~F}$ & $\mathrm{X}^{2}$ \\
\hline Primary purpose viewing polar bears & $74.5 \%$ & $74.8 \%$ & $100 \%$ & $70.8 \%$ & -- & 2.61 \\
\hline Level of Education at Bachelors or above & $73.9 \%$ & $67.5 \%$ & $83.3 \%$ & $77.8 \%$ & -- & 4.32 \\
\hline Group Size & $4.9(5.0)$ & $4.6(4.6)$ & $6.3(7.6)$ & $5.2(5.4)$ & .531 & -- \\
\hline Age & $54(15)$ & $54(15)$ & $59(14)$ & $55(15)$ & .294 & -- \\
\hline Country of Residence & $71.7 \%$ USA & $73.9 \%$ USA & $100 \%$ USA & $63.9 \%$ USA & -- & 4.47 \\
\hline
\end{tabular}

Note: Percentages reported where means were unavailable; Mean (standard deviation); $F=\mathrm{F}$-value, $* * p<.05$ 
Table 3

Trip characteristics summary overall and by cluster group

\begin{tabular}{|c|c|c|c|c|c|c|}
\hline Trip Characteristic & $\begin{array}{l}\text { Study Population } \\
\text { Summary }\end{array}$ & $\begin{array}{l}\text { Cluster } 1 \\
\text { Summary }\end{array}$ & $\begin{array}{l}\text { Cluster } 2 \\
\text { Summary }\end{array}$ & $\begin{array}{l}\text { Cluster } 3 \\
\text { Summary }\end{array}$ & $\mathrm{F}$ & $X^{2}$ \\
\hline Time on Water reported in hours & $3.7(1.9)$ & $3.7(1.8)$ & 4.6(1.6) & $3.7(2.0)$ & .682 & -- \\
\hline Total Polar Bears Seen & $19.8(9.5)$ & $19.4(9.2)$ & $13.8(5.0)$ & $21.1(10.1)$ & 1.950 & -- \\
\hline Length of Stay: Day Trip or & 61.6\% Day & 60.4\% Day & $50.0 \%$ Day & 61.1\% Day & \multirow[t]{3}{*}{--} & \multirow{3}{*}{.389} \\
\hline Overnight Guest & $38.4 \%$ Overnight & $37.8 \%$ Overnight & $50.0 \%$ Overnight & $36.1 \%$ Overnight & & \\
\hline Polar Bears Seen vs Expected & & & & & & \\
\hline Percentage saw more & $80.4 \%$ & $58.6 \%$ & $66.7 \%$ & $58.3 \%$ & \multirow{3}{*}{-- } & \multirow{3}{*}{1.29} \\
\hline Percentage saw less & $14.5 \%$ & $9.9 \%$ & $16.7 \%$ & $11.1 \%$ & & \\
\hline Percentage saw the same & $5.1 \%$ & $2.7 \%$ & $0.0 \%$ & $5.6 \%$ & & \\
\hline Total Time Educated (minutes) & $16.6(16.4)$ & $19.3^{\mathrm{a}}(17.6)$ & $13.3^{\mathrm{ab}}(17.5)$ & $12.7^{\mathrm{b}}(13.6)$ & $* * 3.75$ & -- \\
\hline Epiphany & $31.0 \%$ & $34.2 \%{ }^{\mathrm{a}}$ & $33.3 \%{ }^{\mathrm{ab}}$ & $12.5 \%{ }^{\mathrm{b}}$ & -- & $* * 12.99$ \\
\hline
\end{tabular}

Note. Percentages reported where means were unavailable; Mean (standard deviation); different superscripts within a row indicate significance at $p<.05$ between cluster groups; $F=\mathrm{F}$-value, ${ }^{* *} p<.05$ 
Table 4

Pro-environmental outcomes: overall and by cluster group

\begin{tabular}{|c|c|c|c|c|c|}
\hline Outcomes & $\begin{array}{c}\text { Study } \\
\text { Population }\end{array}$ & Cluster 1 & Cluster 2 & Cluster 3 & $F$ \\
\hline Overall Composite $(\alpha=.957)$ & $5.5(1.0)$ & $5.9^{\mathrm{a}}(0.9)$ & $5.4^{\mathrm{ab}}(1.3)$ & $5.0^{\mathrm{b}}(0.9)$ & $* * 20.15$ \\
\hline Tell others about the population status of polar bears & $5.8(1.2)$ & $6.2^{\mathrm{a}}(1.1)$ & $5.2^{\mathrm{ab}}(1.5)$ & $5.4^{\mathrm{b}}(1.1)$ & **11.98 \\
\hline Write, share, or 'like' something about polar bears on social media & $5.3(1.4)$ & $5.7^{\mathrm{a}}(1.4)$ & $5.2^{\mathrm{ab}}(1.5)$ & $4.9^{\mathrm{b}}(1.3)$ & $* * 7.02$ \\
\hline $\begin{array}{l}\text { Express concern to others about the effects of a warming Arctic } \\
\text { environment on polar bears }\end{array}$ & $5.6(1.2)$ & $5.9^{\mathrm{a}}(1.2)$ & $5.5^{\mathrm{ab}}(1.4)$ & $5.0^{\mathrm{b}}(1.1)$ & $* * 13.56$ \\
\hline Support laws, policies, and actions that help polar bears & $5.7(1.2)$ & $6.1^{\mathrm{a}}(1.1)$ & $5.7^{\mathrm{ab}}(1.2)$ & $5.1^{\mathrm{b}}(1.2)$ & $* * 18.85$ \\
\hline $\begin{array}{l}\text { Encourage others to support laws, policies, and actions that help } \\
\text { protect polar bears }\end{array}$ & $5.5(1.2)$ & $5.9^{\mathrm{a}}(1.1)$ & $5.7^{\mathrm{ab}}(1.5)$ & $5.0^{\mathrm{b}}(1.2)$ & $* 14.12$ \\
\hline Tell others about the loss of Arctic sea ice & $5.7(1.2)$ & $6.1^{\mathrm{a}}(1.1)$ & $5.3^{\mathrm{ab}}(1.4)$ & $5.2^{\mathrm{b}}(1.1)$ & $* * 13.99$ \\
\hline $\begin{array}{l}\text { Write, share, or 'like' something about Arctic sea ice loss on social } \\
\text { media }\end{array}$ & $5.2(1.4)$ & $5.5^{\mathrm{a}}(1.4)$ & $5.2^{\mathrm{ab}}(1.5)$ & $4.7^{\mathrm{b}}(1.2)$ & $* * 8.69$ \\
\hline $\begin{array}{l}\text { Express concern to others about the effects of a warming Arctic } \\
\text { environment on Arctic sea ice }\end{array}$ & $5.6(1.2)$ & $5.9^{\mathrm{a}}(1.2)$ & $5.7^{\mathrm{ab}}(1.2)$ & $5.0^{\mathrm{b}}(1.1)$ & $* * 15.46$ \\
\hline $\begin{array}{l}\text { Support laws, policies, and actions that work to reduce Arctic sea ice } \\
\text { loss and the warming of the Arctic environment }\end{array}$ & $5.6(1.3)$ & $6.1^{\mathrm{a}}(1.1)$ & $5.7^{\mathrm{ab}}(1.4)$ & $5.0^{\mathrm{b}}(1.2)$ & $* * 20.10$ \\
\hline Live in ways that help lessen the warming of the Arctic environment & $5.4(1.3)$ & $5.8^{\mathrm{a}}(1.2)$ & $5.2^{\mathrm{ab}}(1.4)$ & $4.9^{\mathrm{b}}(1.1)$ & $* * 11.47$ \\
\hline $\begin{array}{l}\text { Encourage others to live in ways that helps lessen the warming of the } \\
\text { Arctic environment }\end{array}$ & $5.3(1.2)$ & $5.7^{\mathrm{a}}(1.3)$ & $5.5^{\mathrm{ab}}(1.4)$ & $4.8^{\mathrm{b}}(1.1)$ & $* * 10.86$ \\
\hline $\begin{array}{l}\text { Encourage others to support laws, policies, and actions that work to } \\
\text { reduce Arctic sea ice loss and the warming of the Arctic environment }\end{array}$ & $5.5(1.3)$ & $5.9^{\mathrm{a}}(1.2)$ & $5.5^{\mathrm{ab}}(1.4)$ & $4.9^{\mathrm{b}}(1.2)$ & $* * 15.88$ \\
\hline
\end{tabular}

Note. Mean (Standard deviation) scores on a scale from 1(much less likely) to 7(much more likely); different superscripts

within a row indicate significance at $p<.05$ between cluster groups; $F=$ F-value, ${ }^{* *} p \leq .001$ 
Table 5

Multiple linear regression analysis

\begin{tabular}{|c|c|c|c|c|c|}
\hline \multirow[b]{2}{*}{ Trip Characteristics } & \multicolumn{5}{|c|}{ Overall Outcome Composite } \\
\hline & Grp. & $\mathrm{B}$ & SE B & $\beta$ & $t$-test \\
\hline \multirow{3}{*}{ Time on Water (hours) } & FSP & .043 & .072 & .078 & .604 \\
\hline & $\mathrm{C} 1$ & .049 & .101 & .088 & .485 \\
\hline & $\mathrm{C} 3$ & .104 & .108 & .211 & .963 \\
\hline \multirow{3}{*}{ Total Polar Bears Seen } & FSP & -.028 & .011 & -.267 & $*-2.513$ \\
\hline & $\mathrm{C} 1$ & -.027 & .015 & -.274 & -1.803 \\
\hline & $\mathrm{C} 3$ & -.013 & .019 & -.129 & -.671 \\
\hline \multirow{3}{*}{ Length of Stay: Day vs Overnight } & FSP & .095 & .261 & .046 & .363 \\
\hline & $\mathrm{C} 1$ & .210 & .318 & .108 & .660 \\
\hline & $\mathrm{C} 3$ & -.475 & .455 & -.236 & -1.044 \\
\hline \multirow{3}{*}{ Polar Bears Seen vs Expected } & FSP & -.117 & .161 & -.066 & -.724 \\
\hline & $\mathrm{C} 1$ & -.027 & .226 & -.015 & -.121 \\
\hline & $\mathrm{C} 3$ & -.058 & .233 &.-038 & -.249 \\
\hline \multirow{3}{*}{ Total Time Educated (minutes) } & FSP & .017 & .005 & .278 & *3.298 \\
\hline & $\mathrm{C} 1$ & .009 & .006 & .172 & 1.437 \\
\hline & $\mathrm{C} 3$ & .034 & .012 & .404 & $* 2.860$ \\
\hline \multirow{3}{*}{ Epiphany } & FSP & .547 & .182 & .255 & *3.002 \\
\hline & $\mathrm{C} 1$ & .605 & .221 & .319 & *2.731 \\
\hline & $\mathrm{C} 3$ & .099 & .340 & .041 & .290 \\
\hline
\end{tabular}

Note: Abbreviation meanings- Grp(group), FSP(full study population), C1(Cluster 1), C2(Cluster $2) ; *$ designates significance at $\mathrm{p} \leq 0.05$; FSP: $\mathrm{R}=.232$, Durbin-Watson=1.77; Cluster 1: $\mathrm{R}=.228$, Durbin-Watson=1.74; Cluster 2: $\mathrm{R}=.248$, Durbin-Watson=1.96 


\section{APPENDIX 2017 Phase I Visitor Survey}

1. Before you arrived in the Kaktovik area, were you aware that the waters where boatbased viewing of polar bears occurs...

... are part of the Arctic National Wildlife Refuge (i.e., Arctic Refuge)?

$\square$ Yes $\square$ No

... are managed by the U.S. Fish and Wildlife Service?

\section{Yes $\square$ No}

... are intended to protect wildlife, offer recreational experiences and values in a remote and natural setting, conserve natural diversity, and provide for subsistence uses?

$\square$ Yes $\square$ No

2. When did you arrive in Kaktovik? $\rightarrow$ Month

Day

3. When do you plan to depart Kaktovik? $\rightarrow$ Month Day

4. Have you visited the Kaktovik area of the Arctic Refuge to view polar bears before?

Yes $\rightarrow$ including this visit, how many times?

$\square$ No

5. Have you visited other places to view polar bears?

$\square$ Yes $\rightarrow$ Where? $\rightarrow$ How many times

$\square$ No

6. How much time on this trip have you spent so far...

...in a boat viewing polar bears? $\rightarrow$

...on land viewing polar bears? $\rightarrow$ ...interacting with Kaktovik community members (not including your guide)? $\rightarrow$ number hours (total) number hours (total) number hours (total)

7. How many polar bears in total did you see on this trip so far while...

...you were in a boat?

...you were on land?

8. How many polar bears in total did you expect to see by this point in your trip? 
9. a. What did you like most about your time on the water viewing polar bears?

b. What did you like least about your time on the water viewing polar bears?

10. Why did you choose the Kaktovik area of the Arctic National Wildlife Refuge as your polar bear viewing destination instead of somewhere else?

11. Please rate how important each of the following was to your experience in the Kaktovik area of the Arctic Refuge. THEN rate how satisfied you are with this aspect of your experience during your visit. If you did not participate in an activity or are otherwise uncertain of your answer then leave that line entirely blank.

\begin{tabular}{|c|c|c|c|c|c|c|c|c|c|c|}
\hline \multicolumn{5}{|c|}{$\begin{array}{c}\text { Importance } \\
\text { Circle one number for each } \\
\text { item }\end{array}$} & & \multicolumn{5}{|c|}{\begin{tabular}{|c|} 
Satisfaction \\
Circle one number for each \\
item
\end{tabular}} \\
\hline 蒙 & & 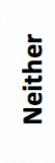 & & 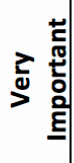 & & 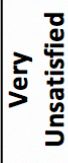 & & $\frac{\grave{ \pm}}{\frac{ \pm}{2}}$ & & > \\
\hline 1 & 2 & 3 & 4 & 5 & Seeing the Arctic landscape and ocean & 1 & 2 & 3 & 4 & 5 \\
\hline 1 & 2 & 3 & 4 & 5 & Viewing polar bears while on the water & 1 & 2 & 3 & 4 & 5 \\
\hline 1 & 2 & 3 & 4 & 5 & Viewing polar bears while on land & 1 & 2 & 3 & 4 & 5 \\
\hline 1 & 2 & 3 & 4 & 5 & Viewing polar bears in a remote, primitive setting & 1 & 2 & 3 & 4 & 5 \\
\hline 1 & 2 & 3 & 4 & 5 & Viewing polar bears without windows to obstruct your view & 1 & 2 & 3 & 4 & 5 \\
\hline 1 & 2 & 3 & 4 & 5 & Viewing polar bears without other boats obstructing your view & 1 & 2 & 3 & 4 & 5 \\
\hline 1 & 2 & 3 & 4 & 5 & Not disturbing or impacting polar bears while viewing them & 1 & 2 & 3 & 4 & 5 \\
\hline 1 & 2 & 3 & 4 & 5 & Viewing polar bears from a safe distance & 1 & 2 & 3 & 4 & 5 \\
\hline 1 & 2 & 3 & 4 & 5 & Viewing polar bears up close & 1 & 2 & 3 & 4 & 5 \\
\hline 1 & 2 & 3 & 4 & 5 & Viewing polar bears from a small boat & 1 & 2 & 3 & 4 & 5 \\
\hline 1 & 2 & 3 & 4 & 5 & Photographing polar bears & 1 & 2 & 3 & 4 & 5 \\
\hline 1 & 2 & 3 & 4 & 5 & Having a local guide who is a resident of Kaktovik & 1 & 2 & 3 & 4 & 5 \\
\hline 1 & 2 & 3 & 4 & 5 & Learning science-based information about polar bears & 1 & 2 & 3 & 4 & 5 \\
\hline 1 & 2 & 3 & 4 & 5 & Learning Native Alaskan-based knowledge about polar bears & 1 & 2 & 3 & 4 & 5 \\
\hline 1 & 2 & 3 & 4 & 5 & $\begin{array}{l}\text { Learning or seeing the effects of a warming Arctic environment on } \\
\text { polar bears }\end{array}$ & 1 & 2 & 3 & 4 & 5 \\
\hline 1 & 2 & 3 & 4 & 5 & Hiking/walking around Kaktovik or Barter Island & 1 & 2 & 3 & 4 & 5 \\
\hline 1 & 2 & 3 & 4 & 5 & Taking a driving tour around Kaktovik or Barter Island & 1 & 2 & 3 & 4 & 5 \\
\hline 1 & 2 & 3 & 4 & 5 & Interacting with Refuge staff & 1 & 2 & 3 & 4 & 5 \\
\hline 1 & 2 & 3 & 4 & 5 & Seeing subsistence hunting/whaling activities & 1 & 2 & 3 & 4 & 5 \\
\hline 1 & 2 & 3 & 4 & 5 & $\begin{array}{l}\text { Interacting with and learning about the local Native Alaskan } \\
\text { community }\end{array}$ & 1 & 2 & 3 & 4 & 5 \\
\hline 1 & 2 & 3 & 4 & 5 & $\begin{array}{l}\text { Polar bear viewing (both yours and others) not disturbing or } \\
\text { impacting the local Native Alaskan community }\end{array}$ & 1 & 2 & 3 & 4 & 5 \\
\hline
\end{tabular}


12. Please indicate the extent that the following issues were problems for you during your visit to the Kaktovik area of the Arctic Refuge. (Check one box for each issue, or indicate that you don't know.)

\begin{tabular}{|c|c|c|c|c|}
\hline & $\begin{array}{c}\text { Not a } \\
\text { Problem }\end{array}$ & $\begin{array}{c}\text { Small } \\
\text { Problem }\end{array}$ & Big Problem & $\begin{array}{l}\text { Don't } \\
\text { Know }\end{array}$ \\
\hline The total number of boats you encountered on the water & 口 & 口 & 口 & DK 口 \\
\hline The number of boats gathered at one time around a bear & $\square$ & $\square$ & $\square$ & DK $\square$ \\
\hline Other boats getting between you and a bear & $\vec{a}$ & $\vec{a}$ & $\vec{\square}$ & DK $\square$ \\
\hline Boats and boat passengers scaring bears & $\square$ & $\square$ & $\square$ & DK $\square$ \\
\hline Not getting close enough when viewing bears & $\square$ & $\square$ & $\square$ & DK $\square$ \\
\hline Getting too close when viewing bears & $\square$ & $\square$ & $\square$ & DK $\square$ \\
\hline Visitors not following rules or behaving badly & $\square$ & $\bar{a}$ & $\bar{a}$ & DK $\square$ \\
\hline Guides not following rules or behaving badly & 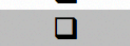 & 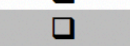 & $\vec{\square}$ & DK $\square$ \\
\hline Safety while on the water & $\square$ & $\square$ & $\square$ & DK \\
\hline Getting adequate information on bears from your guide & 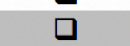 & 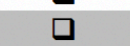 & 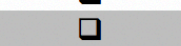 & DK $\square$ \\
\hline Getting adequate information on bears from Refuge staff & $\square$ & $\square$ & $\square$ & DK $\square$ \\
\hline $\begin{array}{l}\text { Negative impacts from the polar bear viewing industry on } \\
\text { the Kaktovik community }\end{array}$ & $\square$ & 口 & $\square$ & DK $\square$ \\
\hline $\begin{array}{l}\text { Concerns with environmental impacts of people traveling to } \\
\text { and staying in Kaktovik to going polar bear viewing }\end{array}$ & 口 & 口 & $\square$ & DK $\square$ \\
\hline Not seeing enough bears & $\square$ & $\square$ & $\square$ & DK $\square$ \\
\hline Seeing bears that were dirty or discolored & $\square$ & $\square$ & $\square$ & DK $\square$ \\
\hline Insufficient amount of time on water viewing polar bears & $\square$ & $\square$ & $\square$ & DK $\square$ \\
\hline Not interacting enough with Kaktovik area residents & $\square$ & $\square$ & $\square$ & DK $\square$ \\
\hline Not interacting enough with Refuge staff & $\square$ & $\square$ & 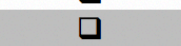 & DK $\square$ \\
\hline Cost of the polar bear viewing trip & $\square$ & $\square$ & $\square$ & DK $\square$ \\
\hline Other (please specify): & $\square$ & $\square$ & $\square$ & DK $\square$ \\
\hline
\end{tabular}

13. We would like to know how far from a polar bear you feel you should be in order to have a safe and enjoyable viewing experience from a boat in the Kaktovik area of the Arctic Refuge.

a. Please rate each photo given to you by indicating how acceptable or unacceptable you think it is based on the distance from a polar bear. A rating of -4 means it is "very unacceptable", and a rating of +4 means it is "very acceptable". (Circle one number for each photo.)

\begin{tabular}{|c|c|c|c|c|c|c|c|c|c|}
\hline & 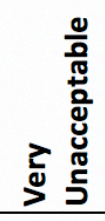 & 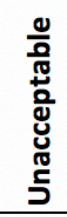 & 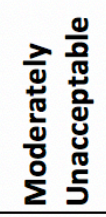 & 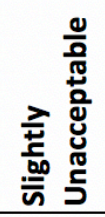 & 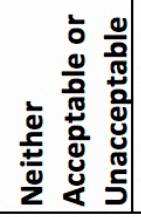 & 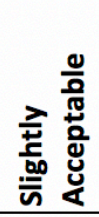 & 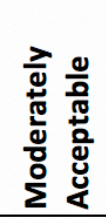 & 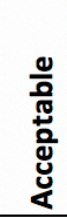 & 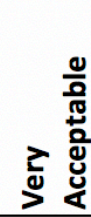 \\
\hline Photo 1 & -4 & -3 & -2 & -1 & 0 & +1 & +2 & +3 & +4 \\
\hline Photo 2 & -4 & -3 & -2 & -1 & 0 & +1 & +2 & +3 & +4 \\
\hline Photo 3 & -4 & -3 & -2 & -1 & 0 & +1 & +2 & +3 & +4 \\
\hline Photo 4 & -4 & -3 & -2 & -1 & 0 & +1 & +2 & +3 & +4 \\
\hline Photo 5 & -4 & -3 & -2 & -1 & 0 & +1 & +2 & +3 & +4 \\
\hline Photo 6 & -4 & -3 & -2 & -1 & 0 & +1 & +2 & +3 & +4 \\
\hline Photo 7 & -4 & -3 & -2 & -1 & 0 & +1 & +2 & +3 & +4 \\
\hline
\end{tabular}


b. Which photo shows the closest you got to a bear during your time on a boat?

Photo number:

$\rightarrow$ How far is the bear in this photo? (specify meters/feet/yards)
OR $\square$ I did not see any bears while on a boat

14. Now, we would like to know how many other boats could be in your view at one time while viewing a polar bear without you feeling too crowded in the remote and rustic setting of the Kaktovik area of the Arctic Refuge.

a. Please rate each photo given to you by indicating how acceptable or unacceptable you think it is based on the number of boats shown. (Circle one number for each photo.)

\begin{tabular}{|c|c|c|c|c|c|c|c|c|c|}
\hline & 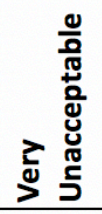 & 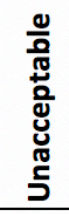 & 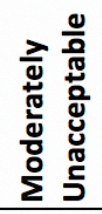 & 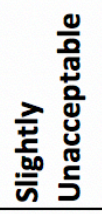 & 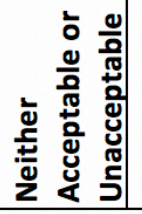 & 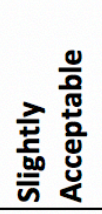 & 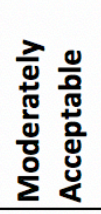 & 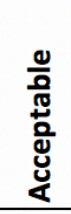 & 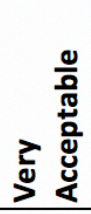 \\
\hline Photo 1 & -4 & -3 & -2 & -1 & 0 & +1 & +2 & +3 & +4 \\
\hline Photo 2 & -4 & -3 & -2 & -1 & 0 & +1 & +2 & +3 & +4 \\
\hline Photo 3 & -4 & -3 & -2 & -1 & 0 & +1 & +2 & +3 & +4 \\
\hline Photo 4 & -4 & -3 & -2 & -1 & 0 & +1 & +2 & +3 & +4 \\
\hline Photo 5 & -4 & -3 & -2 & -1 & 0 & +1 & +2 & +3 & +4 \\
\hline Photo 6 & -4 & -3 & -2 & -1 & 0 & +1 & +2 & +3 & +4 \\
\hline
\end{tabular}

b. Which photo shows the highest number of boats that should be allowed at one time in your view? In other words, at what point should more boats be restricted from gathering around a polar bear because it is too crowded?

Photo number:

OR $\square$ Boats should not be restricted from

OR $\square$ None of the photos gathering around a polar bear at any are so unacceptable that use should be point

c. Which photo shows the level of use that is so unacceptable that you would no longer want to view polar bears in this area?

Photo number:

OR $\square$ None of the photos are so unacceptable that I would no longer want to view polar bears in this area.

d. Which photo looks most like the typical number of boats you saw in your view while viewing a polar bear?

Photo number: 
e. Which photo looks most like the highest number of boats you saw in your view while viewing a polar bear?

Photo number:

15. The Arctic Refuge staff would like to provide polar bear viewing to Refuge visitors in a landscape where the natural sights and sounds, and ongoing human activities of the subsistence community of Kaktovik dominate the effects of polar bear viewing itself. To help judge this, we would like to know how acceptable you think it is to see different percentages of guide boats (i.e., boats viewing polar bears) on the water, moored, and/or beached in the Kaktovik area of the Arctic Refuge.

a. Please rate each percentage of guide boats that would be seen by indicating how acceptable or unacceptable you think it is.

\begin{tabular}{|c|c|c|c|c|c|c|c|c|c|}
\hline & 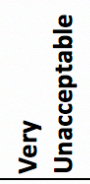 & 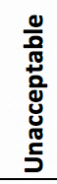 & 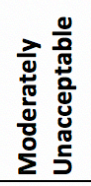 & 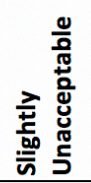 & 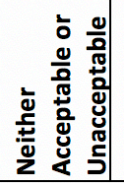 & 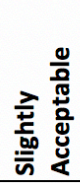 & 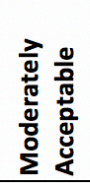 & $\begin{array}{l}\frac{0}{0} \\
\frac{0}{\pi} \\
0 \\
\frac{0}{0} \\
\frac{0}{\alpha}\end{array}$ & 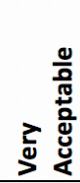 \\
\hline $10 \%$ of boats seen are guide boats & -4 & -3 & -2 & -1 & 0 & +1 & +2 & +3 & +4 \\
\hline $30 \%$ of boats seen are guide boats & -4 & -3 & -2 & -1 & 0 & +1 & +2 & +3 & +4 \\
\hline $50 \%$ of boats seen are guide boats & -4 & -3 & -2 & -1 & 0 & +1 & +2 & +3 & +4 \\
\hline $70 \%$ of boats seen are guide boats & -4 & -3 & -2 & -1 & 0 & +1 & +2 & +3 & +4 \\
\hline $90 \%$ of boats seen are guide boats & -4 & -3 & -2 & -1 & 0 & +1 & +2 & +3 & +4 \\
\hline
\end{tabular}

b. What would you estimate was the percentage of guide boats you saw on the water, moored, and/or beached in the Kaktovik area of the Arctic Refuge?

Percentage of boats seen that OR $\square$ I don't know or cannot estimate were guide boats: __ $\%$ a percentage of guide boats that I saw

16. Please indicate the extent to which you would support or oppose each of the following management strategies if they were needed to help protect the opportunities for and quality of polar bear viewing in the Kaktovik area of the Arctic Refuge.

\begin{tabular}{|c|c|c|c|c|c|c|}
\hline & $\begin{array}{l}\text { Strongly } \\
\text { Oppose }\end{array}$ & Oppose & Neutral & Support & $\begin{array}{l}\text { Strongly } \\
\text { Support }\end{array}$ & $\begin{array}{l}\text { Don't } \\
\text { Know }\end{array}$ \\
\hline \multicolumn{7}{|l|}{ Strategies Applied to Polar Bear Viewing Visitors } \\
\hline Require all visitors to have a guide to go polar bear viewing & 口 & $\square$ & 口 & 口 & 口 & DK \\
\hline Limit the number of visitors who go polar bear viewing & $\square$ & $\square$ & $\square$ & $\square$ & 口 & DK \\
\hline $\begin{array}{l}\text { Limit the amount of time visitors are allowed on the water to } \\
\text { view polar bears }\end{array}$ & a & a & a & a & 口 & DK \\
\hline Require a visitor use fee to go polar bear viewing & $\square$ & $\square$ & $\square$ & $\square$ & $\square$ & DK 口 \\
\hline $\begin{array}{l}\text { Require that a permit for polar bear viewing be obtained by } \\
\text { visitors }\end{array}$ & $\square$ & $\square$ & $\square$ & $\square$ & $\square$ & DK \\
\hline $\begin{array}{l}\text { Limit the number of permits for polar bear viewing that are } \\
\text { available to visitors }\end{array}$ & $\square$ & $\square$ & 口 & $\square$ & $\square$ & DK \\
\hline
\end{tabular}




\begin{tabular}{|c|c|c|c|c|c|c|}
\hline & $\begin{array}{l}\text { Strongly } \\
\text { Oppose }\end{array}$ & Oppose & Neutral & Support & $\begin{array}{l}\text { Strongly } \\
\text { Support }\end{array}$ & $\begin{array}{l}\text { Don't } \\
\text { Know }\end{array}$ \\
\hline Limit the maximum size of visitor groups polar bear viewing & $\square$ & $\square$ & $\square$ & $\square$ & $\square$ & DK ए \\
\hline $\begin{array}{l}\text { Require an orientation for visitors prior to going polar bear } \\
\text { viewing }\end{array}$ & $\square$ & 口 & $\square$ & $\square$ & $\square$ & DK $\square$ \\
\hline $\begin{array}{l}\text { Require visitors to demonstrate that they have the necessary } \\
\text { knowledge to go polar bear viewing }\end{array}$ & $\square$ & $\square$ & $\square$ & $\square$ & $\square$ & DK $\square$ \\
\hline $\begin{array}{l}\text { Require visitors to participate in education about polar bears } \\
\text { and their conservation as part of their experience }\end{array}$ & $\square$ & $\square$ & $\square$ & $\square$ & $\square$ & DK $\square$ \\
\hline Limit the activities that visitors can do while polar bear viewing & $\square$ & $\square$ & $\square$ & $\square$ & $\square$ & DK \\
\hline $\begin{array}{l}\text { Limit what visitor behaviors are allowed while polar bear } \\
\text { viewing }\end{array}$ & $\square$ & $\square$ & $\square$ & $\square$ & $\square$ & DK $\square$ \\
\hline \multicolumn{7}{|l|}{ Strategies Applied to Guides (Note: these would affect visitors too) } \\
\hline $\begin{array}{l}\text { Limit the number of guides that can take people polar bear } \\
\text { viewing }\end{array}$ & $\square$ & 口 & 口 & 口 & 口 & DK $\square$ \\
\hline $\begin{array}{l}\text { Limit the hours that guides can operate to take people polar } \\
\text { bear viewing }\end{array}$ & 口 & 口 & 口 & 口 & 口 & DK \\
\hline $\begin{array}{l}\text { Limit the number of times a guide can launch a boat each day } \\
\text { to take people polar bear viewing }\end{array}$ & 口 & 口 & 口 & 口 & a & DK $\square$ \\
\hline $\begin{array}{l}\text { Limit the maximum number of visitors a guide can take polar } \\
\text { bear viewing at any one time }\end{array}$ & $\square$ & $\square$ & $\square$ & $\square$ & $\square$ & DK $\square$ \\
\hline $\begin{array}{l}\text { Limit the number of boats in any given area at one time while } \\
\text { polar bear viewing }\end{array}$ & $\square$ & $\square$ & $\square$ & $\square$ & $\square$ & DK $\square$ \\
\hline $\begin{array}{l}\text { Limit the size, type, or length of boat that guides use to take } \\
\text { people polar bear viewing }\end{array}$ & $\square$ & $\square$ & $\square$ & 口 & $\square$ & DK $\square$ \\
\hline $\begin{array}{l}\text { Limit the speed of boats or wake that a boat can generate } \\
\text { while taking people polar bear viewing }\end{array}$ & $\square$ & $\square$ & $\square$ & $\square$ & $\square$ & DK $\square$ \\
\hline $\begin{array}{l}\text { Limit the number of polar bearlviewing visitors or trips that a } \\
\text { guide can have during a season }\end{array}$ & $\square$ & $\square$ & $\square$ & 口 & $\square$ & DK $\square$ \\
\hline $\begin{array}{l}\text { Limit the length of the season that guides can offer polar bear } \\
\text { viewing }\end{array}$ & $\square$ & $\square$ & $\square$ & $\square$ & $\square$ & DK $\square$ \\
\hline Require guides to be trained and certified & $\square$ & $\square$ & $\square$ & $\square$ & $\square$ & DK \\
\hline Require guides to offset the carbon footprint of their clients & 口 & 口 & a & 口 & a & DK Q \\
\hline $\begin{array}{l}\text { Designate specific areas where polar bear viewing would not } \\
\text { be allowed to provide a place for bears to escape humans }\end{array}$ & 口 & 口 & ם & 口 & 口 & DK \\
\hline
\end{tabular}

17. a. Has a Refuge staff person talked to you about the status and conservation of polar bear populations during this trip to the Kaktovik area of the Arctic Refuge?

$\square$ Yes $\rightarrow$ For how many minutes total? $\rightarrow$ How many separate times? $\square$ No (skip to Question 18)

b. What did this staff person say was the population status of polar bears in the Arctic Refuge (i.e., in the southern Beaufort Sea)? (Leave blank if they didn't say or you don't remember. Don't answer based on another source):

c. What did the staff person say was the major factor currently influencing polar bear populations in the Arctic Refuge? (Leave blank if they didn't say or you don't remember. Don't answer based on another source): 
18. a. Did your guide talk to you about the status and conservation of polar bear populations during this trip to the Kaktovik area of the Arctic Refuge?

$\square$ Yes $\rightarrow$ For how many minutes total? $\rightarrow$ How many separate times?

$\square$ No (Skip to Question 19)

b. How much did the information about the status and conservation of polar bear populations provided by your guide differ from the information that a Refuge staff person provide you?

$\square$ It did not differ at all

$\square$ It differed a little

$\square$ If differed quite a bit

$\square$ It differed completely

$\square$ I did not talk to a refuge staff person or I do not know

19. Becoming an ambassador for polar bears and the influences of Arctic sea ice loss on them is an important way that people can contribute to the protection of polar bear populations in the Arctic Refuge. How much more or less likely are you to do the following things as a direct result of your experiences in the Kaktovik area of the Arctic Refuge? In other words, how much has your experience changed what you would have done already if you did not visit this place?

\begin{tabular}{|c|c|c|c|c|c|c|c|}
\hline \multirow[b]{2}{*}{ Tell others about the population status of polar bears } & \multicolumn{2}{|c|}{$\begin{array}{l}\text { Much Less } \\
\text { Likely }\end{array}$} & \multicolumn{3}{|c|}{$\begin{array}{c}\text { No change from } \\
\text { what you would } \\
\text { have done }\end{array}$} & \multicolumn{2}{|c|}{$\begin{array}{r}\text { Much More } \\
\text { Likely }\end{array}$} \\
\hline & $\square$ & $\square$ & $\square$ & $\square$ & $\square$ & $\square$ & $\square$ \\
\hline Write, share, or 'like' something about polar bears on social media & $\square$ & $\square$ & $\square$ & $\square$ & $\square$ & $\square$ & $\square$ \\
\hline $\begin{array}{l}\text { Express concern to others about the effects of a warming Arctic } \\
\text { environment on polar bears }\end{array}$ & $\square$ & $\square$ & $\square$ & $\square$ & $\square$ & $\square$ & $\square$ \\
\hline Support laws, policies, and actions that help protect polar bears & $\square$ & $\square$ & $\square$ & $\square$ & $\square$ & $\square$ & $\square$ \\
\hline Tell others about the loss of Arctic sea ice & $\square$ & $\square$ & $\square$ & $\square$ & $\square$ & $\square$ & $\square$ \\
\hline Write, share, or 'like' something about Arctic sea ice loss on social media & $\square$ & $\square$ & $\square$ & $\square$ & $\square$ & 口 & $\square$ \\
\hline $\begin{array}{l}\text { Express concern to others about the effects of a warming Arctic } \\
\text { environment on Arctic sea ice }\end{array}$ & $\square$ & a & $\square$ & $\square$ & $\square$ & a & $\square$ \\
\hline $\begin{array}{l}\text { Support laws, policies, and actions that work to reduce Arctic sea ice loss } \\
\text { and the warming of the Arctic environment }\end{array}$ & $\square$ & a & $\square$ & $\square$ & $\square$ & a & $\square$ \\
\hline Live in ways that help lessen the warming of the Arctic environment & $\square$ & $\square$ & $\square$ & $\square$ & $\square$ & 口 & 口 \\
\hline $\begin{array}{l}\text { Encourage others to live in ways that helps lessen the warming of the } \\
\text { Arctic environment }\end{array}$ & $\square$ & a & 口 & $\square$ & 口 & 口 & $\square$ \\
\hline $\begin{array}{l}\text { Encourage others to support laws, policies, and actions that help protect } \\
\text { polar bears }\end{array}$ & 口 & 口 & 口 & $\square$ & 口 & 口 & $\square$ \\
\hline $\begin{array}{l}\text { Encourage others to support laws, policies, and actions that work to } \\
\text { reduce Arctic sea ice loss and the warming of the Arctic environment }\end{array}$ & 口 & 口 & 口 & ם & 口 & 口 & ם \\
\hline
\end{tabular}


20. If you could ask the Refuge staff to change some things about the way they currently manage polar bear viewing on the water, what would you ask them to do?

(Continue on last page if needed)

21. To what extent did you feel you were in remote, natural setting while viewing polar bears from the water? (Circle one number.)

I never felt like I was in a remote, natural setting

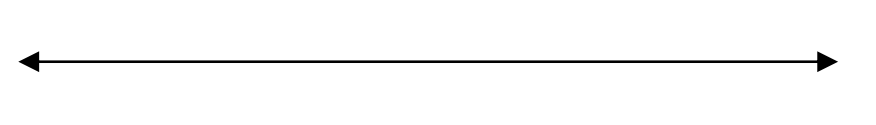

$-1 \quad 0$
I always felt like

I was in remote, natural setting

$-3$

2 3

22. During your time in the Kaktovik area of the Arctic Refuge did you experience any environmental epiphanies, "aha" moments, or moments when your thinking about conservation or your connection to nature really shifted substantially?
$\square$ Yes
$\square$ No
$\square$ Don't know

23. Was viewing polar bears in the Kaktovik area of the Arctic Refuge the primary purpose of your vacation?
$\square$ Yes
$\square$ No

24. What is the highest level of education you have completed?

$\square$ Some High School
$\square$ High School Graduate/GED
$\square$ Some College/Associate's Degree
$\square$ College Graduate (Bachelor's Degree or Equivalent)
$\square$ Post-Graduate Degree (e.g., M.S., Ph.D., J.D.)

25. How many people are in your personal group, including yourself?

26. In what year were you born? 
27. Do you live in the United States? (Please check one and fill in the appropriate blank.)

$\square$ Yes (What is your zip code?

No (What country do you live in?

28. Please provide your email address to allow us to share the results of our survey and to ask you a few additional questions in the future:

Thank you for completing this survey! Please return it to the person who gave it to you.

This information is being collected by Clemson University and Central Michigan University researchers. This survey's results will be provided to Arctic National Wildlife Refuge staff to help them better understand and manage visitors and their polar bear viewing experience. Responses to this request are voluntary and anonymous. Direct comments regarding this survey or other aspect of this data collection to: Dr. Jeffrey C. Hallo, Associate Professor, Clemson University, Department of Parks, Recreation and Tourism Management, 280B Lehotsky Hall, Clemson, SC 29634-0735, jhallo@clemson.edu 
EXAMINING PRO-ENVIRONMENTAL OUTCOMES OF LAST CHANCE TOURISM

\section{REFERENCES}

Aars, J., Derocher, A. E., Andersen, M., Vongraven, D., Ekker, M., \& Wiig, O. (2005). Polar bear management and research in Norway 2001-2005. In Report to the 14th Working Meeting of the IUCN/SSC Polar Bear Specialist Group. Seattle, Washington, USA (pp. 20-24).

Ambassador. (n.d.). In Oxford Living Dictionaries. Retrieved from https://en.oxforddictionaries.com/definition/ambassador

Atwood, T.C., Peacock, E., McKinney, M.A., Lillie, K., Wilson, R., Douglas, D.C., Miller, S., \& Terletzky, P. (2016). Rapid environmental change drives increased land use by an arctic marine predator. PLOS ONE, 11(6).

Avango, D., Nilsson, A.E., \& Roberts, P. (2013). Assessing Arctic futures: voices, resources and governance. The Polar Journal, 3(2), 431-446.

Ballantyne, R., Packer, J., Hughes, K., \& Dierking, L. (2007). Conservation learning in wildlife tourism settings: Lessons from research in zoos and aquariums.

Environmental Education Research, 13(3), 367-383.

Beaumont, N. (2001). Ecotourism and the conservation ethic: Recruiting the uninitiated or preaching to the converted? Journal of Sustainable Tourism, 9(4), 317-341.

Beeco, J.A., \& Hallo, J.C. (2014). GPS tracking of visitor use: factors influencing visitor spatial behavior on a complex trail system. Journal of Park and Recreation Administration, 32(2).

Bogner, F.X. (1998). The influence of short-term outdoor ecology education on longterm variables of environmental perspective. The Journal of Environmental Education, 29(4), 17-29.

Boo, E. (1990). Ecotourism: The potentials and pitfalls. Volume 1. Washington, DC: World Wildlife Fund.

Born, D. (2018). Bearing witness? Polar bears as icons for climate change communication in National Geographic. Environmental Communication.

Bromaghin, J.F., McDonald, T.L., Stirling, I., Derocher, A.E., Richardson, E.S., Regehr, E.V., Douglas, D.C., Durner, G.M., Atwood, T., \& Amstrup, S.C. (2015). Polar bear population dynamics in the Southern Beaufort Sea during a period of sea ice decline. Ecological Applications, 24(3), 634-651. 
EXAMINING PRO-ENVIRONMENTAL OUTCOMES OF LAST CHANCE TOURISM

Burton, M. (2000). Minister of tourism - official opening address. In: Antarctica New Zealand, eds. Proceedings of the Antarctic tourism workshop. Christchurch, NZ: Antarctica New Zealand: 6-7.

Byrne, B. M. (2006). Structural equation modeling with EQS: Basic concepts, applications, and programming (2nd ed.). Mahwah, NJ: Erlbaum.

Caplow, S. (2018). Are we preaching to the same choir? A mixed-methods comparison of audiences at animal-themed interpretive facilities. Journal of Interpretation Research, 23(2), 5-29.

Cessford, G.R. (1995). Conservation benefits of public visits to protected islands. Science and Research Series \#95. Wellington, NZ: Department of Conservation.

Clayton, S., Colléony, A., Conversy, P., Maclouf, E., Martin, L., Torres, A. C., ... \& Prévot, A. C. (2017). Transformation of experience: toward a new relationship with nature. Conservation Letters, 10(5), 645-651.

Colléony, A., Clayton, S., Couvet, D., Saint Jalme, M., \& Prévot, A. C. (2017). Human preferences for species conservation: Animal charisma trumps endangered status. Biological conservation, 206, 263-269.

Dawson, J., Johnston, M.J., Stewart, E.J., Lemieux, C.J., Lemelin, R.H., Maher, P.T., \& Grimwood, B.S.R. (2011). Ethical considerations of last chance tourism. Journal of Ecotourism, 10(3), 250-265.

Dearden, P., Bennett, M., \& Rollins, R. (2007). Perceptions of diving impacts and implications for reef conservation. Coastal Management, 35(2/3), 305-317.

Dowsley, M. (2008). Inuit-organized polar bear sport hunting in Nunavut territory, Canada. Journal of Ecotourism, 8(2), 161-175.

Eijgalaar, E., Thaper, C., \& Peeters, P. (2010). Antarctic cruise tourism: the paradoxes of ambassadorship, "last chance tourism" and greenhouse gas emissions. Journal of Sustainable Tourism, 18(3), 337-354.

Epler, B., Watkins, G. \& Cárdenas, S. (2008). Tourism and the Galápagos economy. in: Galápagos Report 2006-2007, Puerto Ayora, Galápagos, Ecuador, CDF/GNP/INGALA, (pp. 42-47).

Fitzgerald, K.T. (2013). Polar bears: The fate of an icon. Topics on Companion Animal Medicine, 28, 135-142. 
EXAMINING PRO-ENVIRONMENTAL OUTCOMES OF LAST CHANCE TOURISM

Gagnon, R. J., Stone, G. A., \& Garst, B. A. (2017). Beyond composite scores and Cronbach's alpha: advancing methodological rigor in recreation research. Journal of Outdoor Recreation, Education, and Leadership, 9(4).

Gleason, J.S., \& Rode, K.D. (2009). Polar bear distribution and habitat association reflect long-term changes in fall sea ice conditions in the Alaskan Beaufort Sea. Arctic, 62(4), 405-417.

Gössling, S., \& Hall, C. M. (Eds.). (2006). Tourism and global environmental change: Ecological, social, economic and political interrelationships (Vol. 4). Taylor \& Francis.

Halpenny, E.A. (2010). Pro-environmental behavior and park visitors: The effect of place attachment. Journal of Environmental Psychology, 30, 409-421.

Ham, S.H., \& Weiler, B. (2002). Interpretation as the centerpiece of sustainable wildlife tourism, In: R. Harris, T. Griffin, \& P. Williams (Eds.), Sustainable tourism: a global perspective (pp. 35-44). Oxford, Butterworth Heinemann.

Hughes, K. (2013). Measuring the impact of viewing wildlife: Do positive intentions equate to long-term changes in conservation behavior? Journal of Sustainable Tourism, 21(1), 42-59.

Hungerford, H.R., \& Volk, T.L. (1990). Changing learner behavior through environmental education. The Journal of Environmental Education, 21(3), 8-21.

Hvenegaard, G.T. (2002). Using tourist typologies for ecotourism research. Journal of Ecotourism 1(1), 7-18.

Kaktovik. (2018). Retrieved from http://www.north-slope.org/our-communities/kaktovik.

Kaltenborn, B. P., \& Emmelin, L. (1993). Tourism in the high north: Management challenges and recreation opportunity spectrum planning in Svalbard, Norway. Environmental Management, 17(1), 41.

Kim, K., \& Yamashita, E.Y. (2007). Using a K-Means clustering algorithm to examine patterns of pedestrian involved crashes in Honolulu, Hawaii. Journal of Advanced Transportation, 41(1), 69-89.

Koford, K., \& Tschoegl, A. E. (1998). The market value of rarity. Journal of Economic Behavior \& Organization, 34(3), 445-457.

Kollmuss, A., \& Agyeman, J. (2002). Mind the gap: Why do people act environmentally and what are the barriers to pro-environmental behavior? 
EXAMINING PRO-ENVIRONMENTAL OUTCOMES OF LAST CHANCE TOURISM

Kruger, M., Viljoen, A., \& Saayman, M. (2017). Who visits the Kruger National Park and why? Identifying target markets. Journal of Travel and Tourism Marketing, 34(3), 312-340.

Lemelin, H., Dawson, J., Stewart, E.J., Maher, P., \& Lueck, M. (2010). Last-chance tourism: the boom, doom, and gloom of visiting vanishing destinations. Current Issues in Tourism, 13(5), 477-493.

Lemelin, R.H., Dyck, M. (2007). New frontiers in marine wildlife tourism: An international overview of polar bear tourism management strategies. In J. Higham $\&$ M. Luck (Eds.), Marine wildlife and tourism management: Insights from the natural and social sciences (pp. 357-375). Oxfordshire, UK: CAB International.

Lemelin, R.H., \& Smale, B. (2006). Effect of environmental context on the experience of polar bear viewers in Churchill, Manitoba. Journal of Ecotourism, 5(3), 176-191.

Lemelin, R., Stewart, E., \& Dawson, J. (2012). An introduction to last chance tourism. In R. Lemelin \& E. Stewart (Eds.), Last chance tourism: Adapting tourism opportunities in a changing world (pp. 3-9). London, UK: Routledge.

Lemelin, R.H., \& Wiersma, E.C. (2007). Perceptions of polar bear tourists: A qualitative analysis. Human Dimensions of Wildlife, 12, 45-52.

Lindsey, P.A., Alexander, R., Mills, M.G.L., Romañach, S., \& Woodroffe, R. (2007). Wildlife viewing preferences of visitors to protected areas in South Africa: Implications for the role of ecotourism in conservation. Journal of Ecotourism, 6(1), 19-33.

Maher, P.T., Steel, G., McIntosh, A. (2003). Antarctica: tourism, wilderness, and “ambassadorship.” In: A. Watson, J \& Sproull (compilers), Science and stewardship to protect and sustain wilderness values: Seventh World Wilderness Congress symposium (pp. 2-8).

McKay, A.D., Brownlee, M.T., \& Hallo, J.C. (2012). Changes in visitors' environmental focus during an appreciative recreation experience. Journal of Leisure Research, 44(2), 179-200.

Montag, J.M., Patterson, M.E., \& Freimund, W.A. (2005). The Wolf Viewing Experience in the Lamar Valley of Yellowstone National Park, Human Dimensions of Wildlife, 10(4), 273-284. 
EXAMINING PRO-ENVIRONMENTAL OUTCOMES OF LAST CHANCE TOURISM

Nath, R.P.D., Lee, H.J., Chowdhury, N.K., \& Chang, J.W. (2010). Modified K-Means clustering for travel time prediction based on historical traffic data. In International Conference on Knowledge-Based and Intelligent Information and Engineering Systems (pp. 511-521).

Ogunjinmi, A.A. (2016). Segmenting and understanding ecotourists in Nigeria National Parks by environmental attitudes. Nigerian Journal of Forestry 46(2): 57-67.

Orams, M.B. (1997). The effectiveness of environmental education: Can we turn tourists into "Greenies"? Progress in Tourism and Hospitality Research, 3, 295-306.

Piggott-McKellar, A.E. \& McNamara, K.E. (2017) Last chance tourism and the Great Barrier Reef. Journal of Sustainable Tourism, 25(3), 397-415.

Pooley, J.A., \& O’Connor, M. (2000). Environmental education and attitudes: Emotions and beliefs are what is needed. Environment and Behavior, 32(5), 711-723.

Powell, R.B., Brownlee, M.T.J., Kellert, S.R., \& Ham, S.H. (2012). From awe to satisfaction: Immediate affective responses to the Antarctic tourism experience. Polar Record, 48(245), 145-165.

Powell, R.B., \& Ham, S.H. (2008). Can ecotourism interpretation really lead to proconservation knowledge, attitudes, and behavior? Evidence from the Galapagos Islands. Journal of Sustainable Tourism, 16(4), 467-489.

Powell, R.B., Kellert, S.R., \& Ham, S.H. (2009). Interactional theory and the sustainable nature-based tourism experience. Society \& Natural Resources, 22(8), 761-776.

Powell, R.B., Kellert, S.R., \& Ham, S.H. (2008). Antarctic tourists: Ambassadors or consumers? Polar Record, 44(230), 233-241.

Purdie, H. (2013). Glacier retreat and tourism: Insights from New Zealand. Mountain Research and Development, 33(4), 463-472.

Rendón, E., Abundez, I., Arizmendi, A., \& Quiroz, E.M. (2011). Internal versus external cluster validation indexes. International Journal of Computers and Communications, 5(1), 27-34.

Scannell, L., \& Gifford, R. (2010). The relations between natural and civic place attachment and pro-environmental behavior. Journal of Environmental Psychology, 30, 289-297. 
EXAMINING PRO-ENVIRONMENTAL OUTCOMES OF LAST CHANCE TOURISM

Serreze, M.C., Maslanik, J.A., Scambos, T.A., Fetterer, F., Stroeve, J., Knowles, K.,... Haran, T.M. (2003). A record minimum arctic sea ice extent and area in 2002. Geophysical Research Letters, 30(3).

Skibins, J.C., Hallo, J.C., Sharp, J.L., \& Manning, R.E. (2012). Quantifying the role of viewing the Denali "Big 5" in visitor satisfaction and awareness: Conservation implications for flagship recognition and resource management. Human Dimensions of Wildlife: An International Journal, 17(2), 112-128.

Skibins, J.C. \& Powell, R.B. (2013). Conservation caring: Measuring the influence of zoo visitors' connection to wildlife on pro-conservation behaviors. Zoo Biology, 32(5), 528-540.

Skibins, J.C., Powell, R.B., \& Hallo, J.C. (2016). Lucky 13: Conservation implications of broadening "Big 5" flagship species recognition in East Africa. Journal of Sustainable Tourism, 24(7), 1024-1040.

Skibins, J.C., Powell, R.B., \& Hallo, J.C. (2013). Charisma and conservation: Charismatic megafauna's influence on safari and zoo tourists' pro-conservation behaviors. Biodiversity Conservation, 22, 959-982.

Stern, M. J., Powell, R. B., \& Ardoin, N. M. (2008). What difference does it make? Assessing outcomes from participation in a residential environmental education program. The Journal of Environmental Education, 39(4), 31-43.

Stewart, E.J., Wilson, J., Espiner, S., Purdie, H., Lemieux, C., \& Dawson, J. (2016). Implications of climate change for glacier tourism. Tourism Geographies, 18(4), 377-398.

Storie, M., \& Vining, J. (2018). From Oh to Aha: Characteristics and types of environmental epiphany experiences. Human Ecology Review, 24(1), 155-179.

Trave, C., Brunnschweiler, J., Sheaves, M., Diedrich, A., \& Barnett, A. (2017). Are we killing them with kindness? Evaluation of sustainable marine wildlife tourism. Biological Conservation, 209, 211-222.

Tversky, A., \& Kahneman, D. (1974). Judgment under uncertainty: Heuristics and biases. Science, 185(4157), 1124-1131.

UNESCO, United Nations Educational, Scientific and Cultural Organization (2008): Operational Guidelines for the Implementation of the World Heritage Convention. Paris. 
EXAMINING PRO-ENVIRONMENTAL OUTCOMES OF LAST CHANCE TOURISM

United States Fish and Wildlife Services. (2012). Community-based conservation for polar bears. Retrieved from https://www.fws.gov/refuge/arctic/pbcommunity.html

United States Fish and Wildlife Services. (2015). Guided recreational polar bear viewing 2011-2014 summary report. Retrieved from https://www.fws.gov/uploadedFiles/Region_7/NWRS/Zone_1/Arctic/PDF/20112014RecPBViewingRpt.pdf

United States Fish and Wildlife Services. (2016). Polar bear conservation management plan. Retrieved from https://www.fws.gov/alaska/fisheries/mmm/polarbear/pdf/PBRT _Recovery_\%20Plan_Book_FINAL_signed.pdf

United States Fish and Wildlife Services. (2017). Guided recreational polar bear viewing 2015-2016 summary report. Retrieved from https://www.fws.gov/uploadedFiles/ Region_7/NWRS/Zone_1/Arctic/PDF/201516\%20PBV\%20Summary\%20Report.pdf

United States Fish and Wildlife Services. (2018). Guided recreational polar bear viewing 2011-2017 summary report. Manuscript in preparation.

Vila, M., Costa, G., Angulo-Preckler, C., Sarda, R., \& Avila, C. (2016). Contrasting views on Antarctic tourism: 'last chance tourism' or 'ambassadorship' in the last wild. Journal of Cleaner Production, 111, 451-460.

Vining, J. (1992). Environmental emotions and decisions: A comparison of the responses and expectations of forest managers, an environmental group, and the public. Environment and Behavior, 24, 3-34.

Vining, J., \& Merrick, M.S. (2012). Environmental epiphanies: Theoretical foundations and practical applications In S.D. Clayton (Ed.) The Oxford Handbook of Environmental and Conservation Psychology.

Walton, J.K. (2015). Tourism. In Encyclopedia Britannica. Retrieved from https://www.britannica.com/topic/tourism

Weiss, G. M. (2004). Mining with rarity: a unifying framework. ACM Sigkdd Explorations Newsletter, 6(1), 7-19.

Wight, P.A. (2001). Ecotourists: Not a homogeneous market segment. The encyclopedia of ecotourism, 37-62. 
EXAMINING PRO-ENVIRONMENTAL OUTCOMES OF LAST CHANCE TOURISM

Wiig, O., Amstrup, S., Atwood, T., Laidre, K., Lunn, N., Obbard, M., Regehr, E. \& Thiemann, G. (2015). Ursus maritimus. The IUCN Red List of Threatened Species 2015: e.T22823A14871490.

Wilson, R.R., Regehr, E.V., St. Martin, M., Atwood, T.C., Peacock, E., Miller, S., \& Divoky, G. (2017). Relative influences of climate change and human activity on the onshore distribution of polar bears. Biological Conservation, 214, 288-294.

World Heritage Committee. (2018). List of world heritage in danger. Retrieved from http://whc.unesco.org/pg.cfm?cid=86

Zimmerman, E.W. (1951). World resources and industries: A functional appraisal of availability of agricultural and industrial resources. New York: Harper. 